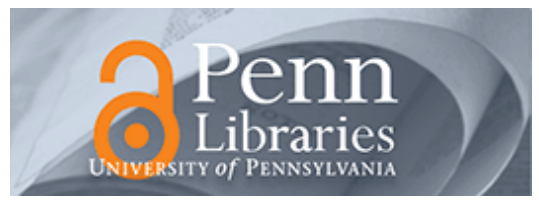

University of Pennsylvania

ScholarlyCommons

Finance Papers

Wharton Faculty Research

2-1-2009

\title{
Do Political Parties Matter? Evidence from U.S. Cities
}

\author{
Fernando V. Ferreira \\ University of Pennsylvania \\ Joseph Gyourko \\ The Wharton School of the University of Pennsylvania
}

Follow this and additional works at: https://repository.upenn.edu/fnce_papers

Part of the Economics Commons, and the Finance and Financial Management Commons

\section{Recommended Citation}

Ferreira, F. V., \& Gyourko, J. (2009). Do Political Parties Matter? Evidence from U.S. Cities. The Quarterly Journal of Economics, 124 (1), 399-422. http://dx.doi.org/10.1162/qjec.2009.124.1.399

This paper is posted at ScholarlyCommons. https://repository.upenn.edu/fnce_papers/43

For more information, please contact repository@pobox.upenn.edu. 


\title{
Do Political Parties Matter? Evidence from U.S. Cities
}

\author{
Abstract \\ Are cities as politically polarized as states and countries? "No" is the answer from our regression \\ discontinuity design analysis, which shows that whether the mayor is a Democrat or a Republican does \\ not affect the size of city government, the allocation of local public spending, or crime rates. However, \\ there is a substantial incumbent effect for mayors. We investigate three mechanisms that could account \\ for the striking lack of partisan impact at the local level, and find the most support for Tiebout \\ competition among localities within metropolitan areas. \\ Disciplines \\ Economics | Finance and Financial Management
}


NBER WORKING PAPER SERIES

DO POLITICAL PARTIES MATTER? EVIDENCE FROM U.S. CITIES

Fernando Ferreira

Joseph Gyourko

Working Paper 13535

http://www.nber.org/papers/w13535

\author{
NATIONAL BUREAU OF ECONOMIC RESEARCH \\ 1050 Massachusetts Avenue \\ Cambridge, MA 02138 \\ October 2007
}

The authors thank the Research Sponsor Program of the Zell/Lurie Real Estate Center at Wharton for financial support. Misha Dworsky, Andrew Moore, Bob Jobim and Igar Fuki provided outstanding research assistance. We also appreciate the comments and suggestions of the editor and referees, as well as Claudio Ferraz, Ed Glaeser, Bob Inman, and seminar participants at the Wharton Applied Economics Workshop, Columbia University, Duke University, Federal Reserve Bank of Philadelphia, IPEA Rio de Janeiro, University of Toronto, and the University of California-Berkeley. The views expressed herein are those of the author(s) and do not necessarily reflect the views of the National Bureau of Economic Research.

(C) 2007 by Fernando Ferreira and Joseph Gyourko. All rights reserved. Short sections of text, not to exceed two paragraphs, may be quoted without explicit permission provided that full credit, including (c) notice, is given to the source. 
Do Political Parties Matter? Evidence from U.S. Cities

Fernando Ferreira and Joseph Gyourko

NBER Working Paper No. 13535

October 2007

JEL No. H7,R38

\begin{abstract}
$\underline{\text { ABSTRACT }}$
We examine whether partisan political differences have important effects on policy outcomes at the local level using a new panel data set of mayoral elections in the United States. Applying a regression discontinuity design to deal with the endogeneity of the mayor's party, we find that party labels do not affect the size of government, the allocation of spending or crime rates, even though there is a large political advantage to incumbency in terms of the probability of winning the next election. The absence of a strong partisan impact on policy in American cities, which is in stark contrast to results at the state and federal levels of government, appears due to certain features of the urban environment associated with Tiebout sorting. In particular, there is a relatively high degree of household homogeneity at the local level that appears to provide the proper incentives for local politicians to be able to credibly commit to moderation and discourages strategic extremism.
\end{abstract}

\author{
Fernando Ferreira \\ Wharton Real Estate Department \\ University of Pennsylvania \\ 1461 Steinberg Hall-Dietrich Hall \\ 3620 Locust Walk \\ Philadelphia, PA 19104 \\ fferreir@wharton.upenn.edu \\ Joseph Gyourko \\ University of Pennsylvania \\ Wharton School of Business \\ 3620 Locust Walk \\ 1480 Steinberg-Dietrich Hall \\ Philadelphia, PA 19104-6302 \\ and NBER \\ gyourko@wharton.upenn.edu
}




\section{Introduction}

Recent research in political economy concludes that political partisanship influences voting behavior, as well as policy and economic outcomes, at the national and state levels of government. Snowberg, Wolfers, and Zitzewitz (2007) use prediction markets to show that expectations about which party controls the executive branch of government in the 2004 presidential election influenced various market prices and indexes, with a higher probability of a Bush victory being associated with higher stock values, interest rates and oil prices, as well as a stronger dollar. Lee, Moretti and Butler (2004) exploit the random variation associated with close U.S. congressional elections in a regression discontinuity (RD) research design to show both that party affiliation explains a very large fraction of the variation in Congressional voting behavior, and that voters essentially are electing policies proposed by political parties instead of affecting the policy positions of the parties. At the state level, Besley and Case (2003) use standard multivariate regression techniques controlling for state and year fixed effects to show that a higher fraction of Democrat party seats in the state legislature is associated with significantly higher state spending per capita, with about one-third of the increase attributable to greater expenditures on family assistance. ${ }^{1}$

There is much less evidence about the potential impact of political partisanship at the local level of government, especially in the United States. ${ }^{2}$ This is unfortunate for a variety of reasons. One is that the local public sector is large in economic terms, with the latest Annual Survey of Governments reporting that nearly 12 million people were employed full time by a county, city, township, or school district in the U.S. Another is that there is reason to suspect that the impact of political partisanship might be different at the local level. Tiebout (1956)-type forces, such as spatial sorting into homogeneous jurisdictions could limit the scope for partisanship even if mayors

\footnotetext{
1 These three papers are only part of a growing body of work on this aspect of political economy. There is now a consensus that U.S. congressional voting behavior is highly partisan, with Lee, Moretti, and Butler's new research design confirming previous results (e.g., see also Poole and Rosenthal (1984) and Snyder and Groseclose (2000)). The evidence regarding the policy impact of which party occupies the Presidency is more mixed, almost certainly due to the difficulty of establishing any robust relationships given the small number of Presidential elections - see Alesina, Roubini and Cohen (1997). At the state level, Besley and Case's (2003) review of the literature notes several other studies that find a material impact of political partisanship on fiscal outcomes (e.g., Grogan (1994), Besley and Case (1995), Knight (2000), and Rogers and Rogers (2000)).

${ }^{2}$ Research on the impact of local politics abroad is more prevalent because of superior data on local election outcomes in other countries. Bertrand and Kramarz (2002) analyze the influence of parties on local zoning boards in France, and find that more restrictive zoning leads to less long-term growth of regional income and employment. More recently, Pettersson-Lidbom (2006) uses a regression discontinuity approach and finds that party labels matter at the local level in Sweden, with cities in which the majority of council representatives belong to left-wing parties having both higher spending and taxes than cities where the majority belongs to right-wing parties. In somewhat related work, Ferraz and Finan (2007) look at the political determinants of corruption in cities in Brazil, and find that an increase in reported corruption substantially reduces the chances of mayoral re-election. Thus, the non-U.S. literature also tends to report strong partisan effects at the local level.
} 
themselves care deeply about policy outcomes. For example, more homogeneity among citizens may facilitate parties credibly committing to moderate policies according to "citizen-candidate" models that generally predict policy divergence (e.g., Alesina (1988), Besley and Coate (1997)). City homogeneity also could limit strategic extremism of the type proposed by Glaeser, Ponzetto and Shapiro (2005), since it becomes harder to win elections by catering to a thin minority with extreme preferences in such circumstances.

Tiebout sorting also raises the possibility that competition among jurisdictions may restrict a politician's desire to pursue highly partisan policies, since local residents can easily move to another local town. Whether 'Tiebout even needs politics' has long been debated in urban economics ${ }^{3}$, but the impact of partisanship on local jurisdictions remains an open empirical question. This issue has also been studied by political scientists, with Peterson (1981) arguing that the competitive nature of the American urban environment limits the scope for redistribution at the local level. If this leads to heightened emphasis on competence in the provision of basic services and not redistribution, the political gains to partisan behavior at the local level could be much smaller.

We use a new data set on mayoral elections to study the impact of political partisanship at the local level in the United States. We collected information on 4,543 direct mayoral elections between 1950 and 2005 in over 400 cities with populations of at least 25,000 residents as of the year 2000. This new data base allows the comparison of actual policy outcomes for elected chief executive officers of different parties, not just the voting behavior of representatives or the market expectation of a future presidential term. More specifically, we estimate the impact of whether the mayor is a Democrat or Republican on local policy outcomes such as the size of local government, the composition of local public expenditures, and the crime rate.

Because the number of cities is large and data were collected over multiple terms of office, we are able to estimate econometric models that use appropriate treatment and control groups. Our empirical research design compares policy outcomes from cities where Democrats barely won an election with cities where Democrats barely lost an election to a Republican. This RD approach pioneered by Lee $(2001,2007)$ provides random variation in party winners across cities with narrow margins of victory. This deals with the endogeneity that exists due to unobserved factors (e.g., the true underlying political leanings of the voters) influencing electoral or political outcomes. A key identification assumption of this research design is that all relevant city characteristics that affect policy are continuous around the narrow margin of victory threshold. We confirm this for a number

\footnotetext{
${ }^{3}$ See Epple and Zelenitz (1981) and Henderson (1985) for contrasting views.
} 
of important local traits including the racial composition of the city, the level of educational achievement of the adult population, and local family income. Thus, we can be confident that these features of the town effectively are being held constant when we estimate the impact of political party on policy.

We find no evidence of partisan differences in any policy outcome examined. Exploiting the quasi-experimental variation associated with close elections is important in reaching this conclusion, as OLS estimates of specifications controlling for a host of local traits indicate that a city which elected a Democrat in the last mayoral election spends 7\% more per capita, raises $8 \%$ more per capita in taxes, and employs $8 \%$ more public workers per capita than an otherwise equivalent city that elected a Republican. Although OLS estimates find no partisan differences in the allocation of those resources across functions such as police, fire, and parks and recreation, they do indicate that cities led by a Democrat mayor have higher violent and property crime rates. However, the more credible RD estimates typically are from 0-40 percent of the magnitudes of the OLS results, and in no case is the remaining estimated partisan gap in local policy outcome statistically different from zero.

Why are local politics less divisive according to the outcomes we examine? Institutional barriers to making changes quickly could explain our results. However, we rule out institutional inertia by comparing outcomes in the final year of the mayor's term, in cities with longer terms of office, and in big cities, always finding no significant partisan differences. Another possible explanation is political weakness. It could be that the mayor's party is highly partisan, but does not have the political strength to move policy to its preferred point. We rule out political weakness as a mechanism after documenting a large political advantage to incumbency. Democrats who barely won the last election are 33 percentage points more likely to win re-election than are Democrats who barely lost, and by much larger margins of victory. This variation in political strength is then used to test a formal model of policy divergence based on Alesina (1988) and Lee, Moretti and Butler (2004) the exploits the panel aspect of our data to examine whether policy outcomes diverge after a subsequent election. Again, we find a high degree of convergence in policy regarding size of government, the allocation of resources across policy function, and for crime rates. Thus, voters are affecting policies implemented by politicians, not merely electing the partisan policy positions of the Democrats or Republicans, which is the opposite of the outcome reported by Lee, Moretti, and Butler (2004) for voting by U.S. representatives. 
We then present evidence that is consistent with Tiebout sorting helping to constrain political partisanship at the local level. First, cities with more than 25,000 people are on average eight times smaller than congressional districts, and they are much more homogeneous with respect to income and political diversity. Second, when we split the sample in half based on the degree of variation in income across census block groups, estimated partisan differences always are larger in the cities with more income heterogeneity, although we lose precision due to the smaller sample sizes involved. In addition, splitting the sample based on the degree of potential competition from nearby jurisdictions (based on a Herfindahl index described later in the paper) yields a similar pattern of results. These Tiebout-type factors associated with the fragmented nature of metropolitan areas in America suggest that local politicians have a reduced scope to appeal to strategic extremism, as well as a greater incentive to commit to moderation.

The plan of the paper is as follows. The next section presents the relevant theories of political divergence. Section III then describes the new data used in our empirical analysis. The main results on partisan differences in terms of the size of local government, crime rates, and the composition of its spending are reported and discussed in Section IV. Analysis of the mechanisms leading to reduced partisanship at the local level is reported in Section V, with the final section containing a brief conclusion.

\section{A Simple Model of Political Partisanship}

The inspiration for economic analysis of political parties dates back to Hotelling's (1929) famous model of spatial competition. While his framework of a 'city on a line' was intended to explain the central location of firms in physical space, Hotelling himself mentions its applicability for understanding the tendency of the Democrat and Republican parties to move toward similar policy positions (on tariffs at the time he wrote). Downs (1957) expanded upon Hotelling's conjecture, building a more formal and elaborate structure with rational voters and political parties. Importantly, the parties cared only about winning elections, and the probability of winning was maximized if they moved to the center of policy space and captured the median voter. ${ }^{4}$ In Downs' framework, democracy and the median voter forced the parties to offer similar platforms, so that the impact of political partisanship on policy outcomes was nil.

\footnotetext{
${ }^{4}$ Downs' (1957) dealt with a variety of other matters pertaining to the way democracy worked, including offering predictions on how two versus three (or more) party systems would function. In this paper, we are only concerned with his implications for the effects (or lack, thereof) of political partisanship in a two-party system.
} 
Downs' convergence result had a powerful influence and became intertwined with the development of median voter models in the fields of urban economics and political economy. ${ }^{5}$ The stark result that partisan politics does not affect policy outcomes at all left many uneasy, and much effort has been made to amend it. Even before Downs wrote, Smithies (1941) challenged Hotelling's pure central location result by pointing out that it relied on an assumption of perfectly inelastic demand at all locations. In that scenario, moving to the center did not cost anything in terms of lower demand on the fringes of the market. However, if demand was elastic, moving away from the edge could be so costly that it was not optimal to locate in the middle of the space. In the language of politics, passionate voters on the extremes might be lost from a move to the center.

Recent work has more formally introduced passion or ideology of the parties and the candidates themselves into the analytical framework. ${ }^{6}$ Intuitively, if a party cares about policy outcomes, not just being elected, locating in the center of policy space may not maximize the utility of its members. However, Alesina (1988) showed that incomplete convergence was about more than whether the party or the candidate cared about something other than being elected. In many contexts, complete convergence is not dynamically consistent because commitments to centrist policies by the political parties are not credible. If parties cannot credibly commit to moderate policies, then they will diverge in policy space. More recent work extending the analysis beyond party preferences to include citizen-candidates also predicts divergence in many settings (Besley and Coate, 1997).

The Alesina (1998) and Besley and Coate (1997) framework readily captures the taste-based partisanship that can arise from candidate or party policy preferences. With respect to mechanisms that might constrain this type of partisanship at the local level, it is easy to see how a greater degree of homogeneity at the jurisdictional level could matter. If the politicians are drawn from a population of more homogeneous citizens, those elected officials who deviate from a representative homogeneous median voter might readily be penalized at the ballot box. If it is easier for local politicians to credibly commit to a centrist policy the more unconstrained Tiebout sorting there is across jurisdictions within a metropolitan area, then less partisanship should be observed in those places. Similarly, more competition in the sense that viable alternative residential locations exist

\footnotetext{
5 Technically speaking, convergence and median voter theorems are not one and the same, as the former is more general than the latter. For our purposes, we can treat them as the same without confusing the interpretation of any of our empirical results.

${ }^{6}$ See Wittman $(1977,1983)$ for early work on politicians' tastes and partisanship. There also is much research in this area by political scientists, but space limitations prevent us from cataloguing or reviewing that work. See the references in Wittman (1983 especially) and in Besley and Case (2003) for more detail.
} 
within a metropolitan area can constrain partisanship. If exit is easy for the voters, indulging one's preferences can be more costly to any given candidate or party. ${ }^{7}$

Glaeser, Ponzetto, and Shapiro (2005) provide another rationale for partisanship, showing that staking out extreme policy positions can be beneficial to a party if it can strategically target messages to its supporters so that donations or turnout are increased sufficiently to raise the probability of winning an election. This mechanism is more powerful when jurisdictions are more heterogeneous, with $50 \%$ of the population favoring liberal policies, for example, while the other $50 \%$ favors more conservative policies. Thus, strategic extremism also could be constrained at the local level by Tiebout sorting. Since cities are on average much smaller and more homogeneous than nations, states or congressional districts ${ }^{8}$, extremism may not be as strategically effective at the local level. The message may positively resonate with only a small fraction of local voters and could negatively impact the majority, thereby hindering one's electoral success.

We next outline a model that very much is in the tradition of Alesina (1988) and Besley and Coate (1997) because their framework is readily understood in terms of our empirical strategy which estimates the degree of policy convergence via a regression discontinuity design. However, the evidence presented later in the paper regarding the mechanisms mediating political partisanship at the local level is germane not only to the issues of political preferences and credible commitment that are central to this strand of the literature, but also to supply-side extremism resulting from strategic behavior.

\section{A. Preferences, Commitment and Policy Convergence}

While Besley and Case's (1997) citizen-candidate model distinguishes between individual candidates and political parties, the key insights regarding partisan impacts hold within a simpler framework in which the process by which parties choose candidates to run in general elections is not explicitly modeled. Because Lee, Moretti, and Butler (2004) already have shown how such a tastebased model of political partisanship can be used to establish the theoretical foundation for an empirical study of the effects of political parties, we adapt their work to our local government context and discuss how the key comparative statics results relate to our empirical estimation.

\footnotetext{
7 Tiebout sorting and the degree of homogeneity in a city may also impact the size and number of jurisdictions in a metropolitan area (e.g., Alesina, Baqir and Hoxby (2004)), but we take these as given in our analysis. ${ }^{8}$ Section $\mathrm{V}$ provides comparisons of the size and homogeneity of cities with congressional districts.
} 
The basic structure, which was first established by Alesina (1988), involves a simple bargaining game between two parties, here denoted as Dems and Reps, that have preferences over a single policy outcome, $S$, the size of local government for example. Each party's utility function is concave in the policy outcome, and the parties' preferred policy outcomes or bliss points are different from one another (and exogenously determined). The Dems' bliss point is defined as $s$ and the Reps is 0 , without loss of generality.

Elections are held at the beginning of each period $t$. Each party announces its policy position just prior to the election. These are denoted $x^{a}$ and $y^{a}$, respectively, for the Dems and Reps. Voters are forward-looking and form rational expectations regarding what policies actually will be implemented. These expectations are formed prior to the election when the outcome is uncertain, and are denoted as $x^{e}$ and $y^{e}$.

The probability that the Dems will win is common knowledge and is given by $P$, with $P=P\left(x^{e}, y^{e}\right)$. In this framework, each voter favors the party closest to his own bliss point and there is uncertainty about the true distribution of voter preferences so that the bliss point of the median voter is not known with certainty. There is an advantage to moving toward the other party in policy space, potentially attracting voters with preferences in between the parties, so $\partial P / \partial x^{e}<0$ and $\partial P / \partial y^{e}$ $<0$ if $x^{e}>y^{e}$.

The efficient frontier of outcomes is given by $x^{*}=y^{*}=\lambda s$, where $\lambda$ ranges in value from 0 to 1 and represents the weight of the Dems in the bargaining process. Note that if $\lambda=1$, the chosen policy is identical to the Dems' preferred size of government. In addition, as long as both parties have concave preferences in the policy outcome, they will prefer a moderate policy with certainty to the electoral win probability weighted-sum of the outcomes $s$ and 0 .

The three possible equilibria from this model are full convergence, full divergence, and partial convergence. Full convergence is the Downs' outcome in which the Dems and Reps announce the same moderate policy and voters expect them to carry out that policy. The latter requires the commitment be credible, and Alesina (1988) first discussed conditions such as low discount rates (which make the parties 'farsighted') that could render commitments believable by the voters. Below, we discuss other mechanisms that also could increase credibility. In this case, the important comparative static results are $d x^{*} / d P^{*}=d y^{*} / d P^{*}=\left(d \lambda^{*} / d P^{*}\right) s>0$, with $P^{*}$ representing the underlying probability the Dems would win at the party bliss points $s=x^{e}$ and $0=y^{e}$. An increase in $P^{*}$ reflects an exogenous increase in the political strength of the Dems, so that their bargaining power is greater and the equilibrium moves closer to their preferred policy position. While the Dems 
obviously prefer a higher $P^{*}$, this should not be confused with them determining the relevant policy outcome in the sense discussed above. Voters are in control here in a classic Downsian sense, as that is what it means when $d x^{*} / d P^{*}>0$ and $d y^{*} / d P^{*}>0$.

The second possible outcome is partial convergence, and it implies that $0<y^{*}<x^{*}<s$. In this scenario, it is still the case that $d x^{*} / d P^{*}>0$ and $d y^{*} / d P^{*}>0$. The intuition is that voters can affect policy to some degree, but are unable to force full convergence. Full divergence is the last possible outcome, and it occurs when $x^{*}=s$ and $y^{*}=0$. That is, the parties implement policies consistent with their bliss points if elected, and voters expected them to do just that. This equilibrium occurs when it is impossible to credibly commit to moderation relative to one's preferred position. In this case, an exogenous increase in the Dem's political strength has no effect on the equilibrium so that $d x^{*} / d P^{*}=d y^{*} / d P^{*}=0$. Voters do not affect the size of government here. The parties determine that, with the voters simply electing one of the parties' bliss points. Empirically, the clearest distinction will be between full divergence and the other two outcomes. This is a test for whether $d x^{*} / d P^{*}$ and $d y^{*} / d P^{*}$ are strictly positive or whether they equal zero.

\section{II.B. Translation Into An Empirical Model}

Because we only observe a policy outcome such as the size of government that is associated with the winning party, it must be written as

(1) $S_{t}=D_{t} x_{t}+\left(1-D_{t}\right) y_{t}$

where $D_{t}$ is a dichotomous dummy variable indicating whether the Dems won the mayoral election in period $t$. To parameterize the key comparative statics, $d x^{*} / d P^{*}$ and $d y^{*} / d P^{*}$, we follow Lee, Moretti, and Butler (2004) and rewrite (1) as

(2) $S_{t}=a+\pi_{0} P_{t}^{*}+\pi_{1} D_{t}+\varepsilon_{t}$,

with the residual $\varepsilon$ capturing the possibility that bliss points can vary across cities. An analogous equation applies for $S$ in period $t+1$. The variable $P_{t}^{*}$ represents the probability of victory assuming the fixed policy platforms represented by $s$ and 0 , so that the estimated coefficient $\pi_{0}$ measures the impact of an increase in the Dems' political strength. An estimate of $\pi_{0}=0$ implies the full 
divergence outcome noted above; $\pi_{0}>0$ implies some amount of convergence. Note that this coefficient is estimated controlling for the pure effect of party, which is captured by the $\pi_{1}$ term.

Since econometricians do not observe the underlying popularity of the Democrat party as represented by $P^{*}$, equation (2) cannot be estimated directly via OLS. However, if there is exogenous variation in whether the Dems win, a set of individual equations can be estimated which allow us to identify all the relevant factors. ${ }^{9}$ For example, the pure party effect (or $\left.\pi_{1}\right)$ from equation (2) can be determined by estimating the average treatment effect in period $t$ :

(3) $E\left\{S_{t} \mid D_{t}=1\right\}-E\left\{S_{t} \mid D_{t}=0\right\}=\pi_{1}$.

This is the expected difference in the size of local government depending on whether the Dems or Reps win the mayor's office. If preferences for policy between Democrats and Republicans are different, and if they are actually able to implement their preferred policies during the mayoral term, then $\pi_{1}$ should be different than zero.

A similar average treatment effect can be estimated for period $t+1$ :

(4) $E\left\{S_{t+1} \mid D_{t}=1\right\}-E\left\{S_{t+1} \mid D_{t}=0\right\}=\pi_{0}\left(P_{D, t+1}^{*}-P_{R, t+1}^{*}\right)+\pi_{1}\left(P_{D, t+1}-P_{R, t+1}\right)=\psi$,

where $P_{D, t+1}$ represents the equilibrium probability of a victory by the Dems in period $t+1$ given that they held the mayor's office in period $t$, while $P_{R, t+1}$ is defined analogously but with a Republican mayor holding office in period $t$. Equation (4) says that the difference in size of local government that occurs after the next election, depending upon whether Dems or Reps won the previous election, can be decomposed into effects due to voters forcing the parties to offer moderate positions (the $\pi_{0}\left(P_{D, t+1}^{*}-P_{R, t+1}^{*}\right)$ component) and those due to purely partisan political differences (the $\pi_{1}\left(P_{D, t+1}-P_{R, t+1}\right)$ component). The left-hand side of (4) is directly observable by comparing policy outcomes between Republicans and Democrats after election $t+1$, and $\pi_{1}$ can be estimated as in (3), but we still need an estimate of $\left(P_{D, t+1}-P_{R, t+1}\right)$ in order to back out the pure partisanship component.

The term $\left(P_{D, t+1}-P_{R, t+1}\right)$ can be thought as the 'incumbent effect', which is defined as the difference in the equilibrium probability that the Dems will win the next mayoral election (in period $t+1)$ depending upon which party won the current election. Another way to think about the

9 The source of exogenous variation comes from the comparison of close elections, as discussed below. 
incumbent effect is that in addition to policy implications, holding the office during a term will also potentially lead to electoral gains at the end of the term. More formally, this electoral advantage from incumbency can be written as:

(5) $E\left\{D_{t+1} \mid D_{t}=1\right\}-E\left\{D_{t+1} \mid D_{t}=0\right\}=P_{D, t+1}-P_{R, t+1}=\gamma$

The product of the pure party effect and the incumbent effect, $\pi_{1}\left(P_{D, t+1}-P_{R, t+1}\right)$, measures the extent to which political parties directly affect policy outcomes via their own preferred positions. As such, it is a reflection of policy divergence. The extent of policy convergence $\pi_{0}\left(P_{D, t+1}^{*}-P_{R, t+1}^{*}\right)$, or of Downsian-type forces, cannot be observed directly but it can be computed as a residual in equation (4). ${ }^{10}$ In section IV, we will estimate equations (3), (4), and (5) using a regression discontinuity approach.

\section{Data Description}

\section{A. Mayoral Elections Survey Data}

The mayoral election data used in this paper were collected from a survey sent to all cities and townships in the United States with more than 25,000 people as of the year 2000. We requested comprehensive information on the timing (year and month) of all mayoral elections since 1950, the name of the mayor and $2^{\text {nd }}$ place candidate, aggregate vote totals and vote totals for each candidate, party affiliation, type of election, and some additional information pertaining to specific events such as runoffs and special elections. ${ }^{11}$

Our sample consists of 4,543 elections held in 413 cities between 1950 and $2005 .^{12}$ The first column of Table 1 reports summary statistics on these cities as of the year 2000. Because we are keenly interested in the representativeness of our sample, the remaining columns in this table report analogous information on different samples of cities. The second column reports data on the

\footnotetext{
${ }^{10}$ We should emphasize that $P_{D, t+1}$ is different from $P_{D, t+1}^{*}$ in these equations. The latter reflects the true electoral strength of the Dems assuming the parties are expected to choose their policy bliss points, $s$ and 0 . This is not observed by the econometrician, which is why the entire term $\pi_{0}\left(P_{D, t+1}^{*}-P_{R, t+1}^{*}\right)$ must be imputed as a residual.

11 The strengths of this survey compared to other publicly available data are readily evident. The Municipal Yearbook, for example, only records the name of the current mayor for a given year, without specifying the year of election. The International City Managers Association (ICMA) only collects data on type of election and organizational features of cities every five years, without asking any question related to election outcomes. The Census of Governments also collects some information about type of election, as well as data on the race and gender of elected officials. Generally, political affiliation is not recorded in these sources.

12 All results reported in this paper are based on data collected through December 2006. Data collection efforts are ongoing, so the sample will be updated periodically. The data are available upon request after publication occurs.
} 
universe of 35,660 American cities. Given our 25,000 population cut-off, it is not surprising that the cities in our sample are more populous than the typical jurisdiction in the country. Bigger cities also tend to have better educated households that earn more money and live in more expensive houses. They also have more minority households, as indicated by the much larger share of the AfricanAmerican population. Regionally, our sample is more heavily weighted towards the West and South, with there apparently being several small towns in the Midwest and North regions that we did not survey.

More relevant is how representative our sample is compared to all 1,893 municipalities with more than 25,000 residents in the year 2000 (column 3). Our sample has larger populations on average, but these two groups are similar in many ways. Not all cities directly elect a mayor and column 4 reports information on the 877 cities that do so. ${ }^{13}$ Our final sample is very similar in demographic, economic, and geographic terms to this group of cities. From survey responses, we were able to obtain at least some information on vote totals and candidate names for $57 \%$ of the 877 cities that elect mayors by popular vote. Summary statistics for this group of 498 places are displayed in Column 5. Our final sample of 413 cities, which is $47 \%$ of those places that directly elect a mayor, also contains information on party affiliation, not just vote totals. ${ }^{14}$

Figure 1 plots the number of observations over time. Not only is the sample growing over time, but there is a cyclical pattern due to a large fraction of cities with two-year term elections. Fifty-one percent of our elections are for 4-year terms, but 44\% are for 2-years only, with 4\% being for 3-year terms. While this means that we work with an unbalanced panel, this feature of the data is not a concern for the research design used in the analysis below. With respect to party affiliation, $51 \%$ of the winners in our sample were Democrats, with $40 \%$ being Republicans. Over time, however, the proportion of Republican mayors has increased substantially as documented in Figure

\footnotetext{
${ }^{13}$ In some cities, the mayor is appointed by or from the city council, while others hire a professional manager to run the locality. The total number of cities that elect a mayor is an estimate that was backed out from three different sources: Census of Governments, ICMA and our own survey. Given that we find some discrepancies among these three sources, it is very likely that the total number of such cities is slightly larger than 877 .

14 Two factors made it difficult to collect information on candidates' party affiliation even when we knew who they were and how many people voted for them. First, some cities and counties could not provide the data because it required gathering information from inaccessible voter registration records. Second, there is a large fraction of cities $(59 \%$ as of year 2000) that are institutionally non-partisan in that they prohibit party labels from being printed on election ballots or used in election campaigning. While this certainly does not mean that nearly $60 \%$ of mayoral races literally had no partisan content, it does signify a major difference with state and federal elections. Indeed, a quick review showed that elections in many such cities (e.g., Los Angeles, CA) clearly were partisan in the standard use of that term. Hence, survey information was complemented with on-line searches for party affiliation information on candidates in several 'non-partisan' cities, by accessing restricted content of local newspapers from News Bank. Overall, approximately $30 \%$ of the party affiliation data for non-partisan cities were found with one of the methods above. The remaining $70 \%$ were collected directly from city or county clerks that were able to access voter registration records.
} 
2. This change is due primarily to an increasing number of wins by Republican candidates, but also reflects in increase in the proportion of independent mayors or mayors from other parties.

The sample of elections used in the regression discontinuity design estimates is further restricted to 1,993 elections because we eliminate races where mayors or second place candidates were from third parties, or when both mayor and runner up candidates belong to the same party. In addition, we only use elections data from 1968-2004 because the fiscal data described below is limited to that time period.

\section{II.B. Local Public Finance Data}

Information on a variety of local public finance variables is merged with the elections data. The public finance data span the fiscal years 1968-2004 and are from the Historical Data Base of Individual Government Finances. These data are based on a Census of Governments conducted every five years, from Annual Survey of Governments collected at every non-census year, and are complemented with state data provided by the Census Bureau. The local public finance variables include measures of revenues and taxes, spending (on current operations and capital goods), employment (full and part time), as well as distributional data regarding shares of spending on labor, public safety, and parks and recreation. Summary statistics on these variables are discussed below in the context of our empirical analysis.

\section{II.C. Crime Data}

Indexes of violent (murder and robbery) and property (burglary and larceny) crime rates are merged with the elections data in order to estimate the potential effect of party affiliation on the efficiency of the provision of police enforcement. The crime data is available at the police district level from the Uniform Crime Reporting reports issued by the FBI and the Department of Justice. We aggregated those measures to the city level and constrained the sample to the 1968-2004 period in order to match the available fiscal data.

\section{Estimation Strategy and Empirical Results}

\section{IV.A. Regression Discontinuity Design Estimation Strategy}

The fundamental identification problem in generating unbiased estimates of the pure party effect $\pi_{1}$ in equation (3) arises from the likelihood that whether or not a Democrat leads a given city is determined by local traits that are unobserved by the econometrician. To deal with this 
endogeneity issue, we compare cities where Democrats barely won an election with cities where Democrats barely lost (and a Republican won). Lee (2001, 2007) demonstrates that this strategy provides quasi-random variation in party winners, since for narrowly decided races, which party wins is likely to be determined by pure chance as long as there is some unpredictable component of the ultimate vote. ${ }^{15}$

More specifically, we estimate the following polynomial functional form for equation $(3)^{16}$ :

$$
\begin{aligned}
\text { (3') } S_{c, t}= & \beta_{0}+D_{c, t} \pi_{1}+M V_{c, \beta} \beta_{1}+M V_{c, \beta_{2}}^{2} \beta_{2}+M V_{c, t}^{3} \beta_{3}+D_{c, t} M V_{c, t} \beta_{4}+D_{c, t} M V_{c, \beta_{5}}^{2} \beta_{5}+ \\
& D_{c, t} M V_{c, \beta_{6}}^{3}+\eta_{c, t}
\end{aligned}
$$

where $M V_{c, t}$ refers to the margin of victory in election $t$ in city $c$ (defined as the difference between the percentage of votes received by the winner and the percentage of votes received by the second place candidate), ${ }^{17}$ and $S_{t}$ represents the policy outcome of interest in the term immediately following election $t$ (i.e., for the size of government variable, it is not the scale of government on election night). Thus, the pure party effect is estimated controlling for the margin of victory in linear, quadratic, and cubic form, as well as interactions of each of these terms with a dichotomous dummy for whether a Democrat won the mayor's race in election $t$ in city $c{ }^{18}$

A similar approach is used to estimate the impact of winning a close election on policy outcomes after election $t+1$ (denoted as $\varphi$ ), as illustrated in equation (4').

$$
\begin{aligned}
\left(4^{\prime}\right) S_{c, t+1}= & \delta_{0}+D_{c, t} \psi+M V_{c, t} \delta_{1}+M V_{c, t}^{2} \delta_{2}+M V_{c, t}^{3} \delta_{3}+D_{c, t} M V_{c, t} \delta_{4}+D_{c, t} M V_{c, t}^{2} \delta_{5}+ \\
& D_{c, t} M V_{c, t}^{3} \delta_{6}+\nu_{c, t} .
\end{aligned}
$$

\footnotetext{
15 That there is randomness in the outcomes of close elections is supported by the fact that Democrat and Republican incumbents do not win a disproportionately high fraction of these close races. Thus, there is no evidence that incumbents are able to systematically rig close elections. These results are available upon request.

16 The RD framework can be estimated parametrically or non-parametrically (see Lee and Card (2005) and Hahn, Todd and Van der Klaauw (2001), respectively). We follow a parametric approach because it allows for straightforward hypothesis testing.

${ }^{17}$ Margin of victory is used in lieu of the vote share in order to facilitate comparison across elections, as some have more than two candidates because of write-in ballots or independent candidates. Non-partisan elections also can have more than one candidate from the same party.

18 The proper order of the polynomial regression is still open to debate in the RD literature, although Porter (2003) argues that odd polynomial orders have better econometric properties. We report results for different functional forms to document that our conclusions are robust to such changes.
} 
Comparing policy outcomes after election $t+1$ provides an estimate of the causal effect of exogenously holding the office during the campaign (i.e., after having won election $t$ ). As we saw in Section II, this can be decomposed into two parts. The first is due to partisan differences in the preferences of each party regarding (say) the size of local government. Mathematically, this is the product of the incumbent effect, $\left(P_{D, t+1}-P_{R, t+1}\right)$, and the pure party effect which is reflected in the $\pi_{1}$ term. The larger this component, the more it is the case that voters are 'electing' a policy by picking one of the parties' bliss points regarding some policy. The second component is that due to Downslike forces of convergence in which the desire to capture the median voter drives the parties to adopt moderate positions (the same position in the extreme). Mathematically, this is the residual from subtracting the first component from the overall effect which is given by $\psi$ in the econometric model. The larger is this component, the more it is the case that the voters are 'affecting' policy in the sense it is the median voter's bliss point, not the political parties' bliss points, which determine the ultimate policy outcome (Lee, Moretti and Butler, 2004).

The incumbent effect itself, which reflects the increased probability of a Democrat winning the next election assuming a Democrat won the previous one, is estimated via equation (5'),

$$
\begin{aligned}
& \text { (5') } D_{c, t+1}=\lambda_{0}+D_{c, t} \gamma+M V_{c, t} \lambda_{1}+M V_{c, t}^{2} \lambda_{2}+M V_{c, \lambda_{3}}^{3} \lambda_{3}+D_{c, t} M V_{c, t} \lambda_{4}+D_{c, t} M V_{c, \lambda_{5}}^{2} \lambda_{5}+ \\
& D_{c, t} M V_{c, \lambda_{6}}^{3} \lambda_{6}+\mathrm{U}_{c, t} \cdot{ }^{19}
\end{aligned}
$$

\section{IV.B. The Incumbent Effect and Changes in Political Strength}

While we are most interested in any partisan impact on policy outcomes, we begin our presentation of results with the incumbent effect, which represents a political rather than a policy outcome. Our RD point estimate of $\gamma$ from equation (5') is 0.323 (standard error $=0.055$ ) which is visually presented on the top left panel of Figure 3. Each dot corresponds to the Democrat party probability of victory in election $t+1$ given the margin of victory obtained by Democrats in election t. The solid line in the figure represents the predicted values from the polynomial fit described in equation (5'), with the dashed lines identifying the 95\% confidence intervals. While margin of victory in the current election and the probability of victory in the next election clearly are positively correlated, the relationship is not continuous. When Democrats barely win an election, they have

\footnotetext{
${ }^{19}$ In addition to Lee $(2001,2007)$, a number of other studies estimate the incumbent effect or the mechanisms leading to the electoral advantage of incumbents. Some important examples in this literature are Alesina and Rosenthal (1989), Snyder (1990), Besley and Case (1995) and Levitt (1996).
} 
about a $66 \%$ chance of winning the next election. In contrast, they win only one third of the time in the subsequent election if they barely lost election $t$, with the difference between those outcomes reflecting the incumbency effect. ${ }^{20}$ The top right panel of Figure 3 then shows that this change in political strength also is reflected in the margin of victory in the next election, with our RD point estimate being 0.248 (standard error $=0.046$ ). Democrat mayors who win election $t$ by a very small margin go on to win in election $t+1$ by a margin of about 5 percentage points. In contrast, if the Democrats barely lost election $t$, they tend to suffer a heavy penalty in the subsequent election, losing by approximately 20 percentage points. Finally, the bottom panels of Figure 3 show the impact of margin of victory in time $t$ on the probability of victory and margin of victory in the previous election as a placebo. As expected, we find no discontinuity in either case.

That incumbency conveys significant political advantage to a political party is consistent with other research on federal office holders. For example, Lee (2007) and Lee, Moretti, and Butler (2004) report 38.5 and 47.6 percentage point incumbency effects, respectively, for U.S. congressional representatives. ${ }^{21}$ While our incumbency effects are slightly smaller, the impact on the margin of victory at the local level is larger than the estimates reported in those two studies. Thus, the political impact of one party holding an office appears to be large across different levels of government. We now proceed to see if the same pattern holds for partisan effects on policy outcomes such as the size of city government, the composition of its spending, and public safety outcomes.

\section{IV.C. RD Estimates of the Party Effect on Local Policy Outcomes}

Table 2 reports our estimates of the partisan impact on a variety of outcomes. Findings are presented for four measures of the size of government (total revenues per capita, total taxes per capita, total expenditures per capita, and total employment per 1,000 residents), four measures of the composition of local public spending (percent spent on wages and salaries, percent spent on police services, percent spent on fire services, and percent spent on parks and recreation), and four measures of the crime rate (murders, robberies, burglaries and larcenies, each measured per 1,000 residents). The first column in Table 2 presents the mean and standard deviation of each of these variables in our sample.

\footnotetext{
${ }^{20}$ Regressions not reported here show this large incumbent effect does not vary much by type of election (partisan versus non-partisan), by size of the city or over time.

21 These are reduced form estimates of the impact of incumbency on the probability of re-election. See Peltzman (1992) for an attempt to estimate the causal relationship between fiscal expenditures and the probability of re-election.
} 
The remaining four columns contain estimates of differences in outcomes in cities with a Democrat rather than a Republican mayor. A positive coefficient always signifies that there is more of the activity in a Democrat-headed city. Columns 2 and 3 report results from OLS specifications. The coefficients listed in column 2 are from a simple specification that regresses the outcome measure on a dichotomous dummy variable that equals one if a Democrat won the last mayoral election, with no other covariates included. Democratic cities have larger governments no matter how one proxies for size. Taxes, spending, and revenues per capita are from 12-13\% higher, and public sector employment is $17 \%$ higher if the mayor is a Democrat and not a Republican. However, these raw partisan differences in the scale of city government do not carry over to differences in the composition of spending. The gap between how the parties spend public resources typically is one percent or less in the functional categories we can track in our data. The results from the bottom panel of column 2 indicate that cities with a Democrat as mayor have higher crime rates, although only the results for the two violent crime measures are statistically different from zero at standard confidence levels.

Column 3's estimates are from OLS specifications that add a number of covariates to the party dummy (see the notes to the table for the details on the other regressors). Not surprisingly, controlling for year and region fixed effects along with a host of city traits lowers the naïve partisan differences from the second column. However, partisan differences in the size of local government still are statistically and economically meaningful, with each scale proxy indicating a city with a Democrat mayor is 7-8\% larger than a comparable city with a Republican mayor. In contrast, the estimated differences in the composition of spending never exceed $0.7 \%$ and none are statistically different from zero at standard confidence levels. Differences in violent crime rates are reduced by a half, while differences in property crimes became negligible and not statistically different than zero.

The remaining columns in Table 2 report RD estimates of $\pi_{\mathrm{t}}$ from two versions of equation (3'). Column 4's results are from a specification in which the margin of victory variable and its interactions are only entered linearly. Column 5's results include quadratic and cubic terms that literally reflect equation ( $\left.3^{\prime}\right)$. That there are no material differences in results across these models illustrates our findings are not sensitive to the specific functional form used in the RD estimation. The RD estimates on differences in the composition of spending remain very small. More interesting is the fact that the RD estimates of partisan impact on the size of government typically are no more than $40 \%$ of the magnitude of the analogous conditional OLS estimates, and none is 
significantly different from zero. ${ }^{22}$ This suggests that unobserved factors were driving a great deal of the OLS differences in policy outcomes. A similar result is found for crime. All OLS differences in violent crimes become smaller in magnitude and insignificantly different than zero, while the estimates for property crimes are still close to zero.

Because pictures often are very illuminating in a regression discontinuity context, Figures 4-6 graph the results from the RD specification reported in column 5 of Table 2 for each group of outcomes. Each dot in a panel corresponds to the average outcome that follows election $t$, given the margin of victory obtained by Democrats in election $t$. The solid line in the figure represents the predicted values from the cubic polynomial fit described in equation (3'), with the dashed lines identifying the $95 \%$ confidence intervals. Visual inspection confirms that there are no significant discontinuities around the close election breakpoint for any of the sixteen outcomes presented in those figures.

\section{IV.D. Formal Test of Political Divergence}

Because we have a panel of elections, we also can test to see if the heightened political strength of incumbents in election $t+1$ is associated with them implementing more partisan policies during the term the follows election $t+1$. Results for this full partisan effect $-\psi$ from equation (4') are reported in the first column of Table 3. Although the point estimates are slightly larger than the pure party effect for the size of government variables, in no case we can reject the null that there is no partisan effect, and we can be confident there are no big effects on the allocation of resources (second panel) or on crime outcomes (third panel). However, the stringent data requirements the regression discontinuity approach imposes lead us to caution against drawing the stark conclusion that there is absolutely no policy divergence due to party partisanship, especially for the size of government measures.

Consequently, we still carry out the decomposition presented in Lee, Moretti and Butler (2004), taking the point estimates at face value (i.e., ignoring the fact that the standard errors are such that we cannot reject estimates of zero). The remaining columns of Table 3 then report the decomposition of our $\psi$ estimate into two components as described in equation (4). Column 2 provides a calculation of the divergence component, or $\pi_{1}\left(P_{D, t+1}-P_{R, t+1}\right)$. Column 3 then notes the difference between the total effect and divergence estimate, which represents the degree of

\footnotetext{
22 The one exception is the cubic specification for total employment. The coefficient falls only by $35 \%$, from 0.075 to 0.049 , in that case.
} 
convergence. The final column reports the percentage of this effect in terms of the overall impact. All but two of the convergence shares are two-thirds or more, which is in stark contrast to the almost zero convergence share found by Lee, Moretti and Butler (2004) for voting behavior in the U.S. House of Representatives. ${ }^{23}$ Overall, these estimates imply that local voters do affect local policy instead of just electing divergent policies from opposing parties.

\section{IV.E. Validity Tests and Robustness Checks}

That our findings of no partisan impact on policy outcomes at the local level of government are in such stark contrast to those discussed above regarding the state and federal governments suggest that thorough validity testing is needed to ensure the results are robust. We begin by investigating a key underlying assumption of the RD approach, which is that cities in which Democrat mayors won a closely contested election are similar on average to cities where Republicans were barely winners. This implies that all observable and unobservable pre-determined features of cities should be similar among those races. More specifically, all relevant observed covariates should be continuous for elections decided by narrow margins of victory. If they are, then it is likely that the unobservables will also be continuous.

We present evidence on the similarity of four sets of pre-determined characteristics of cities in Figure $7 .^{24}$ The upper left panel graphs the results for the average proportion of whites in those cities. As expected, there is a negative relationship between the Democratic margin of victory and the percentage white, but there is no indication of a discontinuity for closely contested races. This is important given research showing that race and ethnicity matter with respect to various fiscal outcomes (e.g., Alesina, Baqir and Easterly, 1999). For our research design which critically relies on random variation associated with very close races for identification, this figure confirms that there is no discrete change in racial composition of cities experiencing closely fought mayoral races. Hence, we can be confident that systematic racial differences are not driving the identifying variation in our RD estimations. Similar patterns are observed for educational achievement (as measured by the fraction of adults with college degree), median family income, and median house prices in the remaining panels of Figure 7 . The Democrat margin of victory is higher the less well-educated are

\footnotetext{
${ }^{23}$ Those two estimates with less than a two-thirds convergence share either reflect a very small total effect or have a very large standard error attached to them.

${ }^{24}$ For brevity, we focus our attention on plots of the data. All underlying regression results are available upon request.
} 
city residents, the lower are median family incomes, and the lower are median house prices, but there is no discontinuity for any of these variables in places with narrowly won elections. ${ }^{25}$

While our main identification assumption certainly appears to be robust, we also estimated equation ( $3^{\prime}$ ) on different samples to see if the main results are stable. These findings, which are reported in Appendix Table 1, always are quite consistent with the main results presented in Table 2. For example, splitting the sample in half based on population size does not yield significantly different results across the two sets of cities. Estimated partisan impacts are always small and never significantly different from zero (see columns 1 and 2 of Appendix Table 1), which indicates that possible differences in the strength of party discipline by city size cannot account for the lack of partisan impact that we find.

Another possible explanation for our finding of no partisan influence on fiscal outcomes is that it takes time to implement changes in tax or spending policy. If so, it could be that partisan effects will only show up later in the mayor's term of office. However, when we re-estimate our equation using data only from the last year of a mayor's term or constraining the sample to four-year term elections, we still find no evidence of partisan differences (see columns 3 and 4 of Appendix Table 1). Moreover, we know from the large incumbency and margin of victory effects reported above that there is significant political value to holding the mayor's office. Even with that political benefit, the formal test of political divergence still found no evidence of partisan influence in a subsequent term. Hence, we conclude that our results cannot be explained by some institutional rigidity that prevents change from occurring. ${ }^{26}$

\section{Does the Urban Environment Mediate Political Partisanship at the Local Level?}

This section investigates whether Tiebout-sorting across municipalities can account for the limited impact of partisanship on policy outcomes at the local level. While estimation of a formal

\footnotetext{
${ }^{25}$ Discontinuity tests for population and geographic location (region of the country) also do not reveal any differential outcome at the cut-off point for close elections. We also investigated the relationships with respect to four predetermined fiscal outcomes: total revenues per capita, total taxes per capita, total current expenditures per capita, and total full time employees per 1,000 residents. They all validated the key identification assumption of continuity for all observed covariates in cities with closely contested elections. We do not present these plots for the sake of brevity, but they all are available upon request.

${ }^{26}$ One noteworthy point is that our sample is restricted to mayors that were elected, so our results cannot be confounded by the elect/non-elect factor documented by Baqir (2002). Of course, there are other institutional features such as whether there is a strong mayor format that could be relevant. We tested this assumption using data from the International City Managers Association (ICMA), which reports various information about city government and election structure, such as if the mayor has veto power. We never find any discontinuity around the close election breakpoint for the variables that serve as a proxy for strong mayors.
} 
structural model of the mechanisms that could be mediating the role of partisanship is beyond the scope of this paper, this section does present suggestive evidence that the degree of heterogeneity within a jurisdiction and the extent of potential competition from other locations within the metropolitan area do matter in this regard. As has been discussed in the Introduction, these possibilities were anticipated by some political scientists and urban economists.

Consider an extreme case in which sorting is perfect and each city is homogenous in the sense that the residents of any given community have the same attributes and desire the same things from local government. In that case, it pays for political parties not to deviate from a 'moderate' position - which is the position of the population in that locale - even if they want a substantially different outcome for partisan reasons. The virtually certain chance of losing the next election if one deviates from an announced moderate position is what would make for a credible commitment by a political party. Of course, this extreme does not exist in reality, but a typical city jurisdiction is more homogeneous than the typical congressional district, metropolitan area, or state.

Table 4 documents this by comparing the heterogeneity of cities and congressional districts along income and political diversity lines. The extent of heterogeneity is measured by the coefficient of variation. This statistic is computed for family income across census block groups within each community in the year 2000 for all cities and congressional districts in the country. ${ }^{27}$ More specifically, the degree of income heterogeneity is measured by the standard deviation of all block group average family incomes in a city divided by the overall city mean family income. For political heterogeneity, we computed the analogous statistic for the proportion of Bush voters in the 2000 election using data at the precinct level that were mapped to city boundaries. ${ }^{28}$

The figures in the second row report information on the population of all cities and congressional districts. Note that cities with more than 25,000 residents are on average eight times smaller than congressional districts, with the median city having almost 44,000 residents versus more than 600,000 in the median congressional district. ${ }^{29}$ In fact, only 15 cities in the United States are more populated than the median Congressional district.

The remaining rows of Table 4 confirm that the typical city is more homogenous along both income and political lines than the typical congressional district. With respect to the coefficient of

\footnotetext{
${ }^{27}$ Census block groups are geographic areas containing approximately 1,000 people.

28 The measure of political diversity can be computed for cities and congressional districts in only 27 states, largely because of a lack of reliable election data for small geographic areas in many parts of the county, and because several states simply do not have geographic identifiers for voting precincts.

${ }^{29}$ Means and medians are reported for the city data especially to reveal the effects of any skewness associated with city size. Constitutional requirements lead the mean and median congressional district to have very similar populations.
} 
variation in income, the median city is less than 40 percent as heterogeneous as the median congressional district $(0.16 / 0.41 \sim 0.39$ from row 3$)$. The difference is less stark, but still quite apparent, if one looks only at larger communities with at least 25,000 residents $(0.32 / 0.41 \sim 0.77)$. And, this conclusion does not change if one uses means which reflect the influence of a few very large cities. Finally, similar qualitative and quantitative results hold if one measures heterogeneity in political terms, as reflected in the local vote share for Bush in the 2000 election.

If more homogeneity in voter traits translates into similar preferences for local public outcomes, as seems likely, we would expect less partisanship no matter whether it is driven by preferences or strategic extremism. With respect to the Alesina (1988) and Besley and Coate (1997) framework, deviating from the center of the distribution could be extremely costly to a candidate or party. In the supply-side driven partisanship model of Glaeser, Ponzetto and Shapiro (2005), the intensive margin that makes strategic extremism viable becomes less valuable the smaller is the variance of voter preferences.

To investigate whether more homogenous cities are less partisan, we first divided our sample in half based on the municipality's coefficient of variation in income and then estimated RD specifications analogous to those reported above on each subsample. Results on the size of government measures are reported in the first two columns of Table $5 .^{30}$ The relatively homogeneous cities with coefficients of variation below the sample median always have very small estimated partisan differences (column one). And, the more heterogeneous cities with greater income variation always have larger estimated partisan differences with respect to size of government measures. The smaller sample sizes involves increase the standard errors, but these results do suggest that Tiebout-type sorting into similar income groups at the city level could be a factor mediating local political partisanship. ${ }^{31}$

We next turn to the issue of whether the presence of competing jurisdictions helps constrain partisanship. To investigate this potential mechanism for mediating the strength of political partisanship, we computed a Herfindahl index based on the adult population (those at least 16 years old) in each city within a metropolitan area. This index is the sum of the squares of the shares of the adult population of the cities located within the same metropolitan area. If there are many cities

\footnotetext{
${ }^{30}$ We also estimated models using the spending allocation and crime indexes as dependent variables for all of the subsamples listed in Table 5. They are not reported for the sake of brevity, but it should be noted that we never find any statistically or economically significant differences in partisan outcomes across the relevant subsamples for any measure. ${ }^{31}$ Results for political diversity present the same pattern, but were much noisier, in part because of the smaller number of observations since the political measure is not available in all states.
} 
within the metropolitan area and they are all small in size, the index value for this area will be very low. Thus, the closer the number is to zero, the more potentially competing locations there are; a value closer to one indicates few viable alternative locations.

As before, we split the cities at the median index value for our sample and estimate the standard RD regressions. Columns 3 and 4 in Table 5 present those results. Note that partisan impacts on the size of government always are larger for the cities in metropolitan areas with less competition in terms of alternative communities in which to locate. And, some of the estimated impacts in the less competitive group are significantly different from zero. Thus, there also is suggestive evidence that political competition of the type existing in a Tiebout-like environment plays a role in mediating the intensity of political partisanship at the local level.

The final two columns of Table 5 report results for subsamples based on the extent of a business presence in the community. More specifically, we compute the number of firms per capita that are located in a city based on the Economic Census of 1997, and split the elections sample by large and small business presence. Peterson (1981) and others have speculated that the size of the business community is a proxy for the potential for redistribution. If so, the scope for partisanship should be greater in cities with a larger commercial presence. The pattern of results still is such that the point estimate of partisan impact always is larger in the communities with a bigger business presence. However, some of these differences are small and the standard errors relatively large.

In sum, Table 4 documents that not only is the population of the typical city much smaller than that of a congressional district, it also is more homogeneous in terms of the incomes and political leanings of its residents. Table 5 then provides suggestive evidence that features of the urban environment associated with Tiebout sorting and the presence of competing jurisdictions can help us understand the small partisan impact we find at the local level. ${ }^{32}$

\section{Summary and Conclusion}

This is the first direct study of the impact of political parties at the local level in the U.S. It relies on information from a new panel data base of mayoral elections. Contrary to a host of recent

\footnotetext{
${ }^{32}$ In addition to estimating the impact of Tiebout sorting, one could also try distinguish between the two primary political economy theories - taste-based versus strategic extremism. We were not successful in this latter effort. We did collect data on religious membership and the number of congregations, as well as union membership information, on the theory that churches and union halls were likely to be useful for strategic extremists wanting to target messages. We performed a number of tests using these data, but the results never provided any meaningful evidence, in part because of a power issue due to measurement error. The problem is that the relevant data are available only at the county or MSA level. This forces us to assume that all cities within a county have similar distributions with respect to unionization rates and religion diversity, which is not correct if Tiebout sorting is occurring within counties or MSAs.
} 
empirical findings concluding that political partisanship plays an important role in determining various policy or economic outcomes and voting behavior at the state and federal levels of government, we find no evidence of a strong partisan influence on the size of city government, the allocation of local public spending across important functions, or on property or violent crime rates. These conclusions depend critically on controlling for the endogeneity of which party wins the mayor's office with a regression discontinuity design that relies on the quasi-experimental variation from closely contested races.

That partisanship does not always dominate suggests that future research in this area begin to focus more closely on identifying the mechanisms and conditions that mediate its influence at all levels of government. A better understanding of the mechanisms that amplify or depress partisanship will allow us to tell if it is feasible to moderate partisanship at higher levels of government (although it is not at all clear such an outcome would be desirable). Our study suggests that spatial sorting into relatively homogenous groups and the presence of competing jurisdictions with the local labor market area provide conditions that help minimize partisanship. These conditions could help parties make credible commitments (Alesina, 1988; Besley and Coate, 1997) or make strategic extremism unattractive to parties (Glaeser, Ponzetto, and Shapiro, 2005).

Another distinctive feature of the local political environment is that there does not appear to be any viable mechanism by which a state or national party leader could pressure a mayor to deviate from policies desired by the median voter in the community. For legislators at the state or federal level, the party leader has a potentially powerful enforcement mechanism through the ability to decide on the assignment to committees of relevance to the legislator's district or the allocation of campaign funds from the state or national party. In fact, Snyder and Groseclose (2000) found a strong influence of the party whip in the legislative setting. Not only is this type of mechanism absent for mayors, but the fundamental Tiebout-like forces in effect at the local level probably would lead to less use of such a mechanism were it available.

Finally, future research should also try to expand beyond our analysis of the size of government and the allocation of resources to policies such as zoning laws and the attraction of new business, among others. It is also possible that the two major political parties may have different views of other aspects of the local public environment (e.g., schools), but we leave such investigation for future empirical work. 


\section{References}

Aghion, Philippe, Alesina, Alberto, and Trebbi, Francesco. "Choosing Electoral Rules: Theory and Evidence from US Cities”, NBER Working Paper no.11236 (2005).

Alesina, Alberto. "Credibility and Policy Convergence in a Two-Party System with Rational Voters", American Economic Review, Vol. 78, no. 4 (1988): 796-805.

Alesina, Alberto, Baqir, Reza, and Easterly, William. "Public Goods and Ethnic Divisions", Quarterly Journal of Economics, Vol. 114 (1999): 1243:1284.

Alesina, Alberto, Baqir, Reza, and Hoxby, Caroline. "Political Jurisdictions in Heterogeneous Communities", Journal of Political Economy, Vol. 112 (2004): 348:396.

Alesina, Alberto and Rosenthal, Howard. "Partisan Cycles in Congressional Elections and the Macroeconomy”, American Political Science Review, Vol. 83 (1989): 373-398.

Alesina, Alberto, Roubini, Nouriel, and Cohen, Gerald. Political Cycles and the Macroeconomy, Cambridge, MA: The MIT Press, 1999.

Baqir, Reza. "Districting and Government Overspending", Journal of Political Economy, Vol. 110, no. 6 (2002): 1318:1354.

Besley, Timothy and Anne Case. "Does Electoral Accountability Affect Economic Policy Choices? Evidence from Gubernatorial Term Limits", Quarterly Journal of Economics, Vol. 110 (1995): 769798.

Besley, Timothy and Anne Case. "Political Institutions and Policy Choices: Evidence from the United States", Journal of Economic Literature, Vol. XLI (2003): 7-73.

Besley, Timothy and Coate, Stephen. "An Economic Model of Representative Democracy", The Quarterly Journal of Economics, Vol. CXII (1997): 85-114.

Bertrand, Marianne and Francis Kramarz. "Does Entry Regulation Hinder Job Creation? Evidence from the French Retail Industry”, Quarterly Journal of Economics, Vol. 117, no. 4 (2002): 1369-1413.

Downs, Anthony. An Economic Theory of Democracy. Boston, MA: Addison-Wesley, 1957.

Epple, Dennis and Allan Zelenitz. "The Implications of Competition Among Jurisdictions: Does Tiebout Need Politics”, Journal of Political Economy, Vol. 89, no. 6 (1981): 1197-1217.

Ferraz, Claudio and Finan, Frederico. "Exposing Corrupt Politicians: The Effect of Brazil's Publicly Released Audits on Electoral Outcomes", forthcoming Quarterly Journal of Economics, (2007).

Glaeser, Edward, Giacomo Ponzetto, and Jesse Shapiro. "Strategic Extremism: Why Republicans and Democrats Divide on Religious Values", Quarterly Journal of Economics, Vol. 120, no. 4 (2005): 1283-1330. 
Glaeser, Edward and Bryce Ward. "Myths and Realities of American Political Geography", Journal of Economic Perspectives, Vol. 20, no. 2 (2006): 119-144.

Grogan, Colleen. "Political-Economic Factors Influencing State Medicaid Policy", Political Research Quarterly, Vol 47, no. 3 (1994): 589-623.

Henderson, J. Vernon. "The Tiebout Model: Bring Back the Entrepreneurs", Journal of Political Economy, Vol. 93, no. 2 (1985): 248-264.

Hotelling, Harold. “Stability in Competition”, Economic Journal, Vol. 39, March (1929): 41-57.

Knight, Brian. "Supermajority Voting Requirements for Tax Increases: Evidence from the States", Journal of Public Economics, Vol 76 (2000): 41-67.

Lee, David. “The Electoral Advantage to Incumbency and Voters' Valuation of Politicians' Experience: A Regression Discontinuity Analysis of Elections to the U.S. House", NBER Working Paper No. 8441, 2001.

Lee, David. "Randomized Experiments from Non-random Selection in U.S. House Elections", Journal of Econometrics, (2007) forthcoming.

Lee, David, Enrico Moretti and Matthew Butler. "Do Voters Affect or Elect Policies? Evidence from the U.S. House”, Quarterly Journal of Economics, Vol. 119, no. 3 (2004): 807-859.

Levitt, Steven. "How Do Senators Vote? Disentangling the Role of Voter Preferences, Party Affiliation, and Senator Ideology", American Economic Review, Vol. 86 (1996): 425-441.

Peltzman, Sam. "Voters as Fiscal Conservatives". Quarterly Journal of Economics, Vol. 107 (1992): $327: 361$.

Peterson, Paul. “City Limits”, University of Chicago Press, 1981.

Pettersson-Lidbom, Per. "Do Parties Matter for Economic Outcomes? A Regression-Discontinuity Approach", working paper 2006.

Poole, Keith and Rosenthal, Howard. "The Polarization of American Politics", Journal of Politics, XLVI (1984): 102-131.

Rogers, Diane Lim and John Rogers. "Political Competition and State Government Size: Do Tighter Elections Produce Looser Budgets?”, Public Choice, Vol. 33, no. 4 (2000): 27-43.

Smithies, Arthur. "Optimum Location in Spatial Competition", Journal of Political Economy, vol. 49, no. 3, (1941): 423-439.

Snowberg, Erik, Wolfers, Justin and Zitzewitz, Eric. "Partisan Impacts and the Economy: Evidence from Prediction Markets and Close Elections", Quarterly Journal of Economics, Vol. 122, no. 2 (2007): 807-830. 
Snyder, James. "Campaign Contributions as Investments: The U.S. House of Representatives, 19801986", Journal of Political Economy, vol. 98 (1990): 1195-1227.

Snyder, James and Groseclose, Timothy. "Estimating Party Influence in Congressional Roll-Call Voting", American Journal of Political Science, XLIV (2000): 187-205.

Tiebout, Charles. "A Pure Theory of Local Public Expenditures", Journal of Political Economy, Vol. 64, no. 5 (1956): 416-424.

Wittman, Donald. “Candidates with Policy Preferences: A Dynamic Model”, Journal of Economic Theory, Vol. 14 (1977): 180-189.

Wittman, Donald. "Candidate Motivation: A Synthesis of Alternative Theories", The American Political Science Review, Vol 77 (1983): 142-157. 
Table 1. Sample representativeness

\begin{tabular}{|c|c|c|c|c|c|}
\hline & $\begin{array}{c}\text { final sample } \\
\text { (1) }\end{array}$ & $\begin{array}{c}\text { all US cities } \\
(2)\end{array}$ & $\begin{array}{c}\text { cities } \\
\text { with }>25000 \\
\text { population } \\
\text { (3) } \\
\end{array}$ & $\begin{array}{c}\text { cities with } \\
>25000 \text {, and } \\
\text { elected mayor } \\
\text { (4) }\end{array}$ & $\begin{array}{c}\text { cities }>25000, \\
\text { elected mayor, } \\
\text { survey reply } \\
(5) \\
\end{array}$ \\
\hline number of cities & 413 & 34,574 & 1,893 & 877 & 498 \\
\hline population & $\begin{array}{c}126,364 \\
(256,768)\end{array}$ & $\begin{array}{c}7,666 \\
(62,732)\end{array}$ & $\begin{array}{c}86,245 \\
(255,000)\end{array}$ & $\begin{array}{c}112,392 \\
(346,409)\end{array}$ & $\begin{array}{c}113,104 \\
(234,874)\end{array}$ \\
\hline$\%$ west & $\begin{array}{c}0.20 \\
(0.40)\end{array}$ & $\begin{array}{c}0.12 \\
(0.33)\end{array}$ & $\begin{array}{c}0.24 \\
(0.42)\end{array}$ & $\begin{array}{c}0.18 \\
(0.39)\end{array}$ & $\begin{array}{c}0.21 \\
(0.41)\end{array}$ \\
\hline$\%$ south & $\begin{array}{c}0.26 \\
(0.44)\end{array}$ & $\begin{array}{c}0.24 \\
(0.43)\end{array}$ & $\begin{array}{c}0.24 \\
(0.43)\end{array}$ & $\begin{array}{c}0.25 \\
(0.44)\end{array}$ & $\begin{array}{c}0.29 \\
(0.45)\end{array}$ \\
\hline$\%$ north & $\begin{array}{c}0.16 \\
(0.36)\end{array}$ & $\begin{array}{c}0.23 \\
(0.42)\end{array}$ & $\begin{array}{c}0.25 \\
(0.43)\end{array}$ & $\begin{array}{c}0.23 \\
(0.42)\end{array}$ & $\begin{array}{c}0.14 \\
(0.35)\end{array}$ \\
\hline$\%$ white & $\begin{array}{c}0.68 \\
(0.22)\end{array}$ & $\begin{array}{c}0.88 \\
(0.20)\end{array}$ & $\begin{array}{c}0.75 \\
(0.19)\end{array}$ & $\begin{array}{c}0.69 \\
(0.23)\end{array}$ & $\begin{array}{c}0.68 \\
(0.22)\end{array}$ \\
\hline$\%$ black & $\begin{array}{c}0.13 \\
(0.17)\end{array}$ & $\begin{array}{c}0.05 \\
(0.14)\end{array}$ & $\begin{array}{c}0.11 \\
(0.16)\end{array}$ & $\begin{array}{c}0.13 \\
(0.17)\end{array}$ & $\begin{array}{c}0.12 \\
(0.17)\end{array}$ \\
\hline$\%$ college degree & $\begin{array}{c}0.26 \\
(0.13)\end{array}$ & $\begin{array}{c}0.17 \\
(0.13)\end{array}$ & $\begin{array}{c}0.28 \\
(0.15)\end{array}$ & $\begin{array}{c}0.26 \\
(0.13)\end{array}$ & $\begin{array}{c}0.26 \\
(0.13)\end{array}$ \\
\hline median family income & $\begin{array}{l}\$ 53,035 \\
(16,202)\end{array}$ & $\begin{array}{l}\$ 46,916 \\
(19,262)\end{array}$ & $\begin{array}{l}\$ 57,927 \\
(19,566)\end{array}$ & $\begin{array}{l}\$ 53,334 \\
(16,687)\end{array}$ & $\begin{array}{l}\$ 53,428 \\
(16,265)\end{array}$ \\
\hline median house value & $\begin{array}{c}\$ 132,622 \\
(66,582)\end{array}$ & $\begin{array}{c}\$ 100,526 \\
(86,412)\end{array}$ & $\begin{array}{l}\$ 156,718 \\
(100,769)\end{array}$ & $\begin{array}{c}\$ 133,838 \\
(70,988)\end{array}$ & $\begin{array}{c}\$ 134,067 \\
(66,961)\end{array}$ \\
\hline
\end{tabular}

Notes: All variables are based on the 2000 Census. Column 1 presents descriptives for the mayoral election sample used in this paper. Column 2 reports descriptives for all cities in the US. Column 3 restricts the sample to cities with more than 25,000 people as of year 2000. Column 4 additionally constrains the sample to cities that directly elect a mayor. Column 5 present results for cities that replied to the survey with vote totals but no information about party affiliation. See the text for additional details. 
Table 2. RD and OLS estimates of differences between Democrat and Republican mayors

\begin{tabular}{|c|c|c|c|c|c|}
\hline \multirow[b]{2}{*}{ dependent variables } & \multirow[b]{2}{*}{$\begin{array}{c}\text { average } \\
(\mathrm{std}) \\
(1) \\
\end{array}$} & \multicolumn{4}{|c|}{$\%$ difference between Dems and Reps } \\
\hline & & $\begin{array}{c}\text { OLS } \\
\text { unconditional } \\
(2) \\
\end{array}$ & $\begin{array}{c}\text { OLS } \\
\text { conditional } \\
(3) \\
\end{array}$ & $\begin{array}{c}\text { RD } \\
\text { Linear } \\
(4) \\
\end{array}$ & $\begin{array}{c}\mathrm{RD} \\
\text { Cubic } \\
(5) \\
\end{array}$ \\
\hline \multicolumn{6}{|l|}{ size of government } \\
\hline total revenues per capita & $\begin{array}{c}\$ 1,347 \\
(853)\end{array}$ & $\begin{array}{c}0.127 \\
(0.030)\end{array}$ & $\begin{array}{c}0.071 \\
(0.025)\end{array}$ & $\begin{array}{c}0.017 \\
(0.033)\end{array}$ & $\begin{array}{c}0.033 \\
(0.054)\end{array}$ \\
\hline total taxes per capita & $\begin{array}{l}\$ 794 \\
(597)\end{array}$ & $\begin{array}{c}0.122 \\
(0.033)\end{array}$ & $\begin{array}{c}0.083 \\
(0.024)\end{array}$ & $\begin{array}{c}0.053 \\
(0.032)\end{array}$ & $\begin{array}{l}-0.005 \\
(0.053)\end{array}$ \\
\hline total expenditures per capita & $\begin{array}{c}\$ 1,353 \\
(846)\end{array}$ & $\begin{array}{c}0.124 \\
(0.031)\end{array}$ & $\begin{array}{c}0.068 \\
(0.026)\end{array}$ & $\begin{array}{c}0.009 \\
(0.033)\end{array}$ & $\begin{array}{c}0.028 \\
(0.055)\end{array}$ \\
\hline total employment per 1000 residents & $\begin{array}{l}14.7 \\
(9.2)\end{array}$ & $\begin{array}{c}0.169 \\
(0.034)\end{array}$ & $\begin{array}{c}0.075 \\
(0.027)\end{array}$ & $\begin{array}{c}0.036 \\
(0.036)\end{array}$ & $\begin{array}{c}0.049 \\
(0.059)\end{array}$ \\
\hline \multicolumn{6}{|l|}{ allocation of resources } \\
\hline$\%$ spent with salaries and wages & $\begin{array}{c}0.50 \\
(0.12)\end{array}$ & $\begin{array}{c}0.008 \\
(0.006)\end{array}$ & $\begin{array}{c}0.007 \\
(0.006)\end{array}$ & $\begin{array}{c}0.012 \\
(0.007)\end{array}$ & $\begin{array}{c}0.005 \\
(0.013)\end{array}$ \\
\hline$\%$ spent with police department & $\begin{array}{c}0.18 \\
(0.08)\end{array}$ & $\begin{array}{c}-0.01 \\
(0.004)\end{array}$ & $\begin{array}{l}-0.003 \\
(0.004)\end{array}$ & $\begin{array}{l}-0.001 \\
(0.005)\end{array}$ & $\begin{array}{l}-0.002 \\
(0.008)\end{array}$ \\
\hline$\%$ spent with fire department & $\begin{array}{c}0.11 \\
(0.05)\end{array}$ & $\begin{array}{l}-0.005 \\
(0.003)\end{array}$ & $\begin{array}{l}-0.003 \\
(0.003)\end{array}$ & $\begin{array}{c}0.004 \\
(0.003)\end{array}$ & $\begin{array}{c}0.007 \\
(0.006)\end{array}$ \\
\hline$\%$ spent with parks and recreation & $\begin{array}{c}0.08 \\
(0.07)\end{array}$ & $\begin{array}{l}-0.014 \\
(0.004)\end{array}$ & $\begin{array}{l}-0.007 \\
(0.003)\end{array}$ & $\begin{array}{l}-0.004 \\
(0.004)\end{array}$ & $\begin{array}{l}-0.003 \\
(0.007)\end{array}$ \\
\hline crime indexes & & & & & \\
\hline murder per 1000 residents & $\begin{array}{c}0.08 \\
(0.10)\end{array}$ & $\begin{array}{c}0.024 \\
(0.006)\end{array}$ & $\begin{array}{c}0.008 \\
(0.004)\end{array}$ & $\begin{array}{c}0.006 \\
(0.006)\end{array}$ & $\begin{array}{c}0.001 \\
(0.008)\end{array}$ \\
\hline robbery per 1000 residents & $\begin{array}{c}2.09 \\
(3.59)\end{array}$ & $\begin{array}{c}0.883 \\
(0.196)\end{array}$ & $\begin{array}{c}0.473 \\
(0.186)\end{array}$ & $\begin{array}{c}0.537 \\
(0.294)\end{array}$ & $\begin{array}{c}0.490 \\
(0.426)\end{array}$ \\
\hline burglary per 1000 residents & $\begin{array}{c}16.1 \\
(13.2)\end{array}$ & $\begin{array}{c}1.789 \\
(0.798)\end{array}$ & $\begin{array}{c}0.488 \\
(0.734)\end{array}$ & $\begin{array}{c}0.766 \\
(0.861)\end{array}$ & $\begin{array}{l}-0.106 \\
(1.188)\end{array}$ \\
\hline larceny per 1000 residents & $\begin{array}{c}42.8 \\
(28.5)\end{array}$ & $\begin{array}{c}3.318 \\
(1.789)\end{array}$ & $\begin{array}{c}2.222 \\
(1.757)\end{array}$ & $\begin{array}{c}2.810 \\
(2.210)\end{array}$ & $\begin{array}{l}-0.224 \\
(2.935)\end{array}$ \\
\hline covariates & & $\mathrm{NO}$ & YES & YES & YES \\
\hline observations & & 1993 & 1993 & 1993 & 1993 \\
\hline
\end{tabular}

Notes: Column 1 presents averages and standard deviations for all independent variable, while Columns 2 to 5 report coefficients from OLS and RD regressions of the independent variables indicated in the table on an indicator variable for whether the mayor is a Democrat, and other controls as described in equation (4') in the text. All size of government variables were transformed to logs in the OLS regressions. The set of covariates include city population, the type of election (partisan versus non-partisan, length of term status), median income, percentage of white households, percentage of households with college degree, homeownership rate and the median house value. Year and region fixed effects also are included. See the text for a more detailed explanation of the fiscal and crime variables. Reported standard errors are clustered by city and decade. 
Table 3. Total partisanship effect decomposition

\begin{tabular}{|c|c|c|c|c|}
\hline dependent variables & $\begin{array}{c}(1) \\
\text { total impact } \\
(\psi)\end{array}$ & $\begin{array}{c}(2) \\
\text { divergence } \\
\prod_{1}\left(\mathrm{PD}_{t+1}-\mathrm{PR}_{t+1}\right)\end{array}$ & $\begin{array}{c}(3) \\
\text { convergence } \\
(1)-(2) \\
\end{array}$ & $\begin{array}{c}\text { (4) } \\
\text { convergence } \\
\text { share (3)/(1) }\end{array}$ \\
\hline \multicolumn{5}{|l|}{ size of government } \\
\hline total revenues & $\begin{array}{c}0.07 \\
(0.06)\end{array}$ & 0.011 & 0.061 & $85 \%$ \\
\hline total taxes & $\begin{array}{c}0.01 \\
(0.06)\end{array}$ & -0.001 & 0.016 & $110 \%$ \\
\hline total expenditures & $\begin{array}{c}0.08 \\
(0.06)\end{array}$ & 0.009 & 0.072 & $89 \%$ \\
\hline total employment per 1000 residents & $\begin{array}{c}0.09 \\
(0.06)\end{array}$ & 0.016 & 0.073 & $82 \%$ \\
\hline \multicolumn{5}{|l|}{ allocation of resources } \\
\hline$\%$ spent with salaries and wages & $\begin{array}{c}0.01 \\
(0.01)\end{array}$ & 0.002 & 0.004 & $73 \%$ \\
\hline$\%$ spent with police department & $\begin{array}{l}-0.01 \\
(0.01)\end{array}$ & -0.001 & -0.007 & $92 \%$ \\
\hline$\%$ spent with fire department & $\begin{array}{c}0.00 \\
(0.01)\end{array}$ & 0.002 & 0.001 & $25 \%$ \\
\hline$\%$ spent with parks and recreation & $\begin{array}{l}-0.01 \\
(0.01)\end{array}$ & -0.001 & -0.007 & $88 \%$ \\
\hline \multicolumn{5}{|l|}{ crime indexes } \\
\hline murder per 1000 residents & $\begin{array}{c}0.01 \\
(0.01)\end{array}$ & 0.000 & 0.006 & $95 \%$ \\
\hline robbery per 1000 residents & $\begin{array}{c}0.30 \\
(0.64)\end{array}$ & 0.158 & 0.143 & $47 \%$ \\
\hline burglary per 1000 residents & $\begin{array}{l}-0.17 \\
(1.28)\end{array}$ & -0.034 & -0.138 & $80 \%$ \\
\hline larceny per 1000 residents & $\begin{array}{l}-2.03 \\
(3.01)\end{array}$ & -0.072 & -1.959 & $96 \%$ \\
\hline
\end{tabular}

Notes: Column 1 presents RD coefficient estimates of each fiscal policy outcome after election $\mathrm{t}+1$ on an indicator for Democrat victory in election $t$ and other controls as described in equation (4') in the text. All size of government variables were transformed to logs. Covariates include city population, the type of election (partisan versus non-partisan, length of term status), median income, percentage of white households, percentage of households with college degree, homeownership rate and the median house value. Year and region fixed effects also are included. Reported standard errors are clustered by city and decade. Column 2 multiplies the incumbent effect and the pure party effect estimated in Table 2. Column 3 subtracts column 2 from column 1. Finally, Column 4 calculates the ratio of column 3 over column 1. For additional details see equation (4) in the text. 
Table 4. Comparisons between cities and congressional districts

\begin{tabular}{|c|c|c|c|c|c|c|}
\hline & \multicolumn{2}{|c|}{ Cities } & \multicolumn{2}{|c|}{ Cities, $>=25,000$ pop. } & \multicolumn{2}{|c|}{ Congressional Districts } \\
\hline & mean & median & mean & median & mean & median \\
\hline number of jurisdictions & \multicolumn{2}{|c|}{23,394} & \multicolumn{2}{|c|}{1,887} & \multicolumn{2}{|c|}{435} \\
\hline population & 10,976 & 2,769 & 85,236 & 43,789 & 645,377 & 633,102 \\
\hline income heterogeneity & 0.18 & 0.16 & 0.33 & 0.32 & 0.43 & 0.41 \\
\hline political heterogeneity & 0.15 & 0.10 & 0.26 & 0.21 & 0.36 & 0.30 \\
\hline
\end{tabular}

Notes: Number of jurisdictions and population are based on the 2000 Census. The income heterogeneity measure is based on the coefficient of variation for income, and it was calculate using block group mean and median incomes from the 2000 Census for the entire country. The political heterogeneity measure also is measured by the coefficient of variation based on the precinct level vote share for Bush in the 2000 presidential election. Voting precincts could be only accurately mapped to municipalities for the following states: CA, CT, IL, IN, MA, ME, NH, NJ, NY, OH, PA, RI, VT, WI, CO, DE, GA, HI, KS, MD, MN, NC, OK, TX, VA, WA, and WV. 
Table 5. Tests of convergence mechanisms

\begin{tabular}{|c|c|c|c|c|c|c|}
\hline \multirow[b]{2}{*}{ dependent variables } & \multicolumn{6}{|c|}{ RD Cubic, \% difference between Dems and Reps } \\
\hline & $\begin{array}{c}\text { (1) } \\
\text { income } \\
\text { homog. } \\
\text { group }\end{array}$ & $\begin{array}{c}\text { (2) } \\
\text { income } \\
\text { heterog. } \\
\text { group }\end{array}$ & $\begin{array}{c}(3) \\
\text { less } \\
\text { fragmented } \\
\text { group } \\
\end{array}$ & $\begin{array}{c}(4) \\
\text { more } \\
\text { fragmented } \\
\text { group } \\
\end{array}$ & $\begin{array}{c}\text { (5) } \\
\text { small } \\
\text { business } \\
\text { presence }\end{array}$ & $\begin{array}{c}\text { (6) } \\
\text { large } \\
\text { business } \\
\text { presence }\end{array}$ \\
\hline \multicolumn{7}{|l|}{ size of government } \\
\hline total revenues per capita & $\begin{array}{l}-0.02 \\
(0.07)\end{array}$ & $\begin{array}{c}0.08 \\
(0.08)\end{array}$ & $\begin{array}{c}0.14 \\
(0.09)\end{array}$ & $\begin{array}{l}-0.09 \\
(0.06)\end{array}$ & $\begin{array}{c}0.05 \\
(0.08)\end{array}$ & $\begin{array}{c}0.09 \\
(0.08)\end{array}$ \\
\hline total taxes per capita & $\begin{array}{l}-0.07 \\
(0.08)\end{array}$ & $\begin{array}{c}0.07 \\
(0.07)\end{array}$ & $\begin{array}{l}-0.02 \\
(0.07)\end{array}$ & $\begin{array}{l}-0.04 \\
(0.08)\end{array}$ & $\begin{array}{l}-0.05 \\
(0.08)\end{array}$ & $\begin{array}{c}0.06 \\
(0.07)\end{array}$ \\
\hline total expenditures per capita & $\begin{array}{l}-0.03 \\
(0.07)\end{array}$ & $\begin{array}{c}0.09 \\
(0.08)\end{array}$ & $\begin{array}{c}0.13 \\
(0.09)\end{array}$ & $\begin{array}{l}-0.08 \\
(0.07)\end{array}$ & $\begin{array}{c}0.05 \\
(0.08)\end{array}$ & $\begin{array}{c}0.09 \\
(0.08)\end{array}$ \\
\hline total employment per 1000 residents & $\begin{array}{l}-0.04 \\
(0.08)\end{array}$ & $\begin{array}{c}0.12 \\
(0.08)\end{array}$ & $\begin{array}{c}0.16 \\
(0.09)\end{array}$ & $\begin{array}{l}-0.06 \\
(0.07)\end{array}$ & $\begin{array}{c}0.03 \\
(0.09)\end{array}$ & $\begin{array}{c}0.15 \\
(0.07)\end{array}$ \\
\hline covariates & YES & YES & YES & YES & YES & YES \\
\hline observations & 978 & 1004 & 974 & 989 & 903 & 929 \\
\hline
\end{tabular}

Notes: All columns present RD coefficient estimates from different sub-samples, where each fiscal policy outcome was regressed on an indicator for Democrat victory in election t and other controls as described in equation (4') in the text. All size of government variables were transformed to logs. Columns 1 and 2 split the full sample according to the median coefficient of variation of income, based on the 2000 Census data. Columns 3 and 4 split the sample according to the median Herfindahl index based on the adult population of each city in a metropolitan area as of year 2000. Columns 5 and 6 split the full sample according to the number of firms present in each city, based on the 1997 Economic Census. Reported standard errors are clustered by city and decade. 
Figure 1. Number of elections

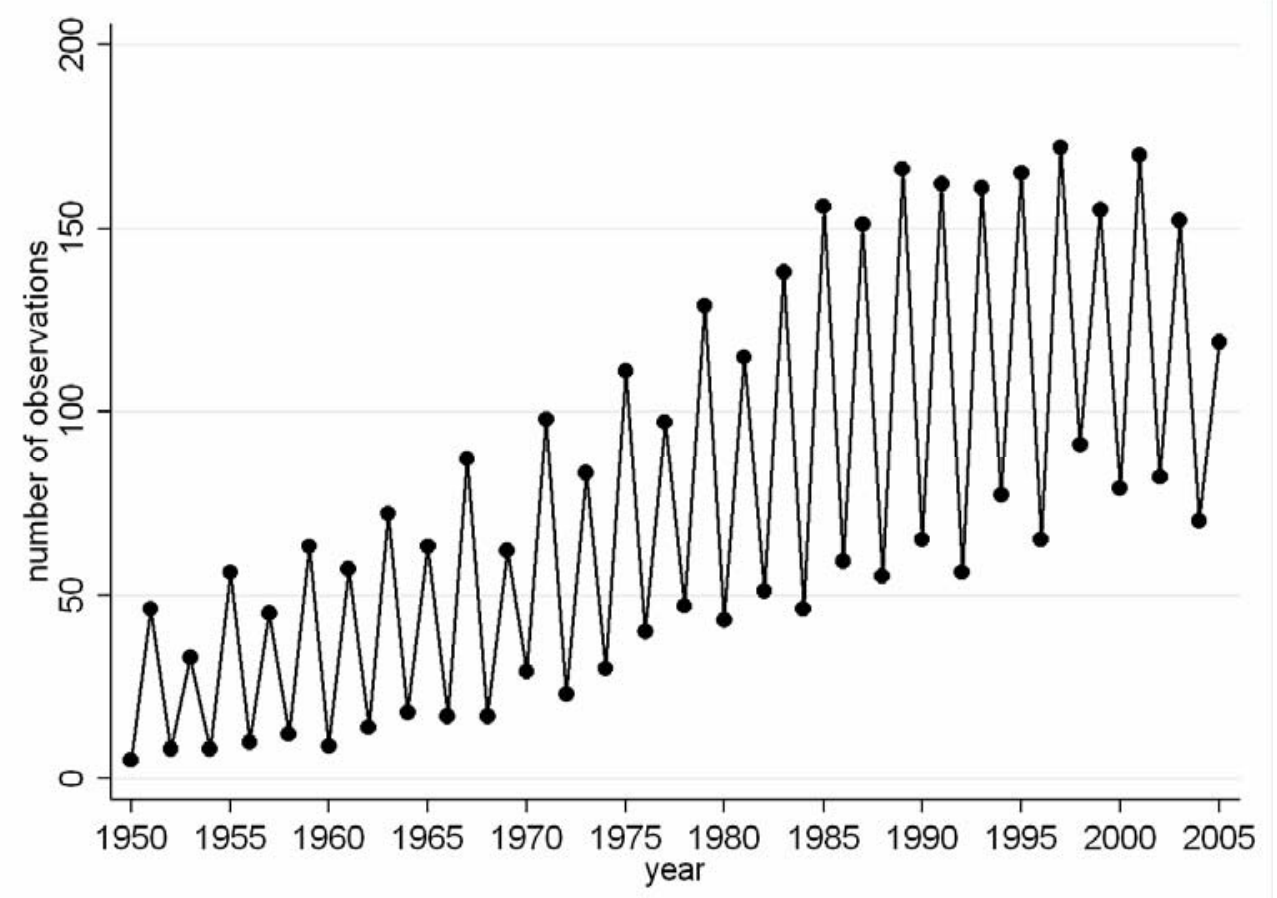

Notes: The figure shows the total number of observations in our sample of mayoral elections by year.

Figure 2. Percentage of Democrat and Republican mayors

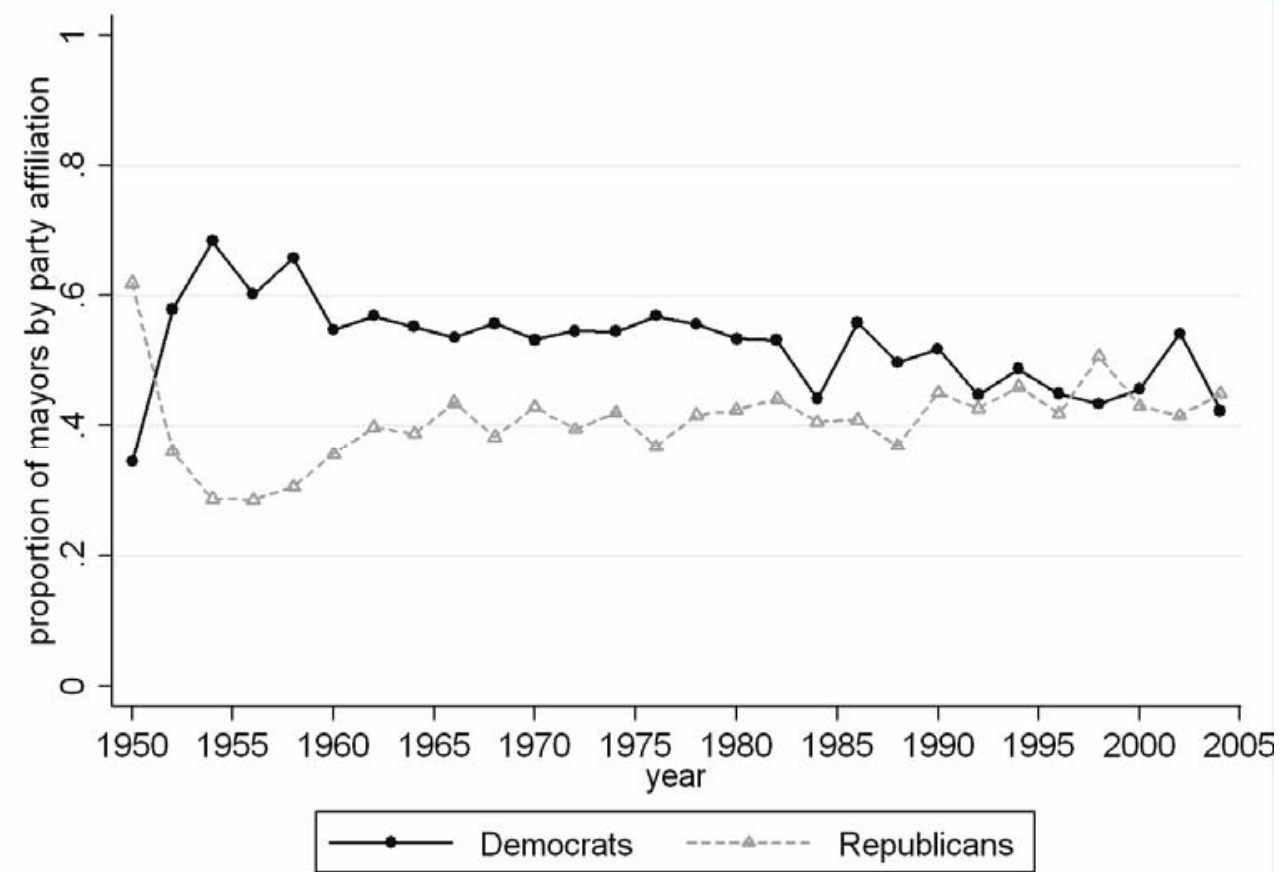

Notes: The figure shows the proportion of Democratic and Republican mayors by year of election. 
Figure 3. Incumbent effect
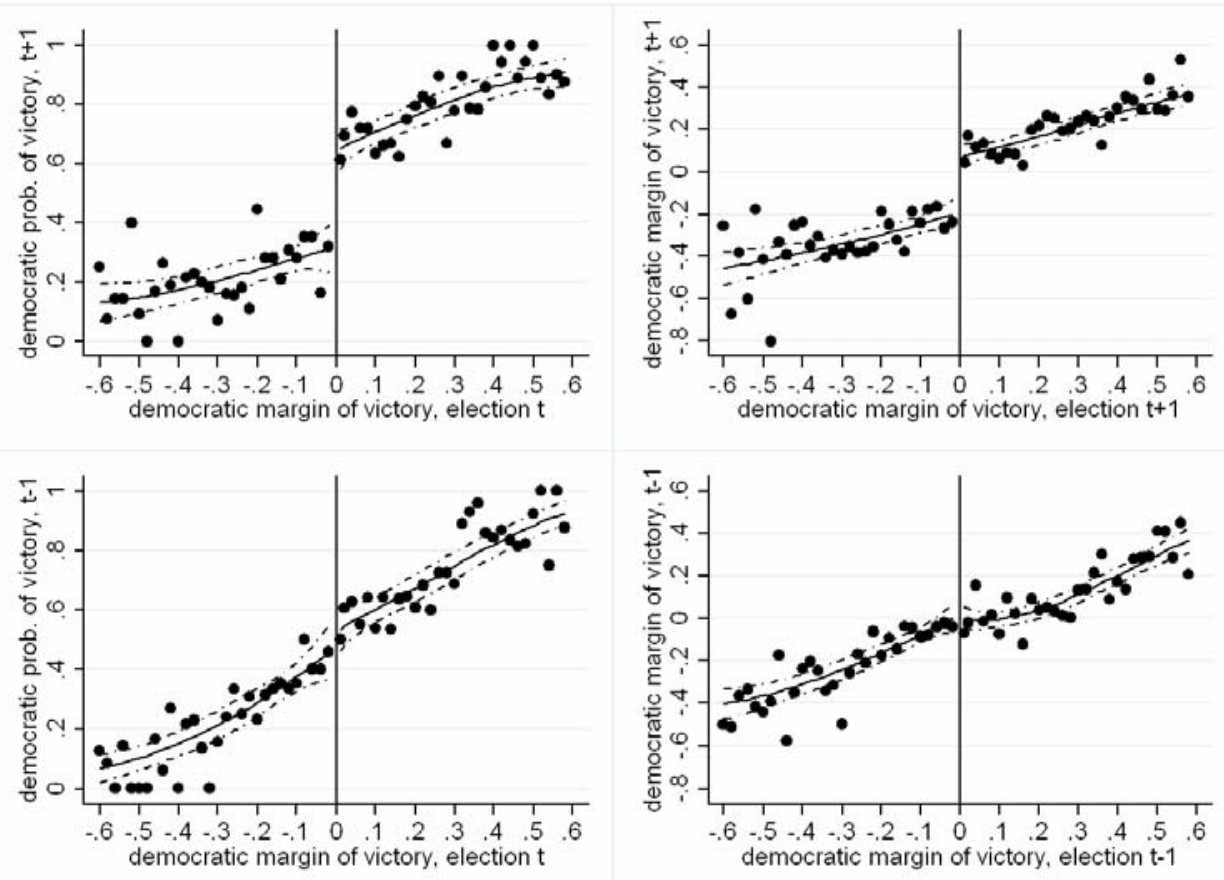

Notes: The top panels (from left to right) refer to the Democratic probability of victory in election $t+1$ and to the Democratic margin of victory in election $t+1$. The bottom panels refer to the same variables in election $t-1$. Each dot corresponds to the unconditional mean within intervals of 0.02 Democratic margin of victory in election $t$. The solid line represents the predicted values of a third-order polynomial fit described in equation ( $\left.5^{\prime}\right)$, with the dashed lines showing the $95 \%$ confidence intervals.

Figure 4. Party effect on size of government
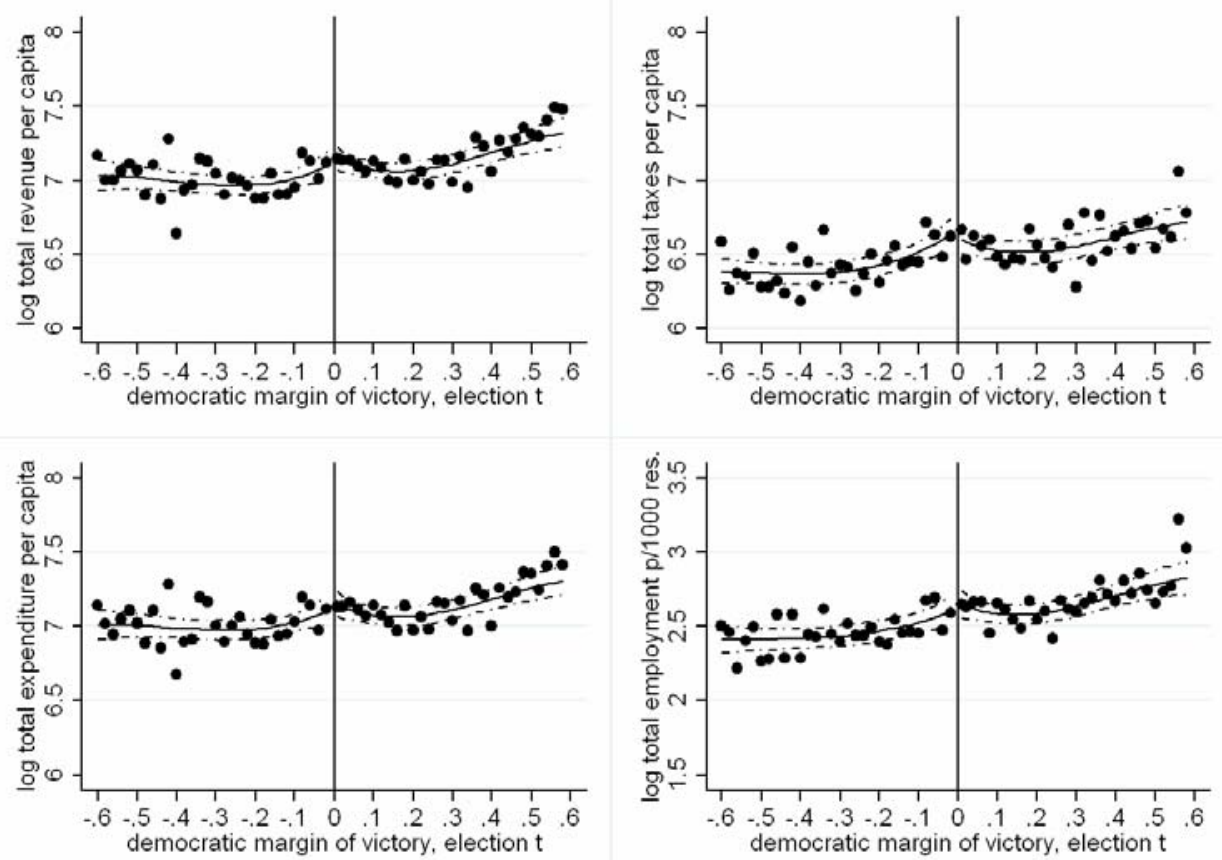

Notes: The panels (from top left to bottom right) refer to the following outcomes: log total revenues per capita, log total taxes per capita, log total expenditures per capita and log total employment per 1,000 residents. All monetary measures are as of year 2000. Each dot corresponds to the unconditional mean within intervals of 0.02 Democratic margin of victory in election $t$. The solid line represents the predicted values of a third-order polynomial fit described in equation (3'), with the dashed lines showing the $95 \%$ confidence intervals. 
Figure 5. Party effect on allocation of resources
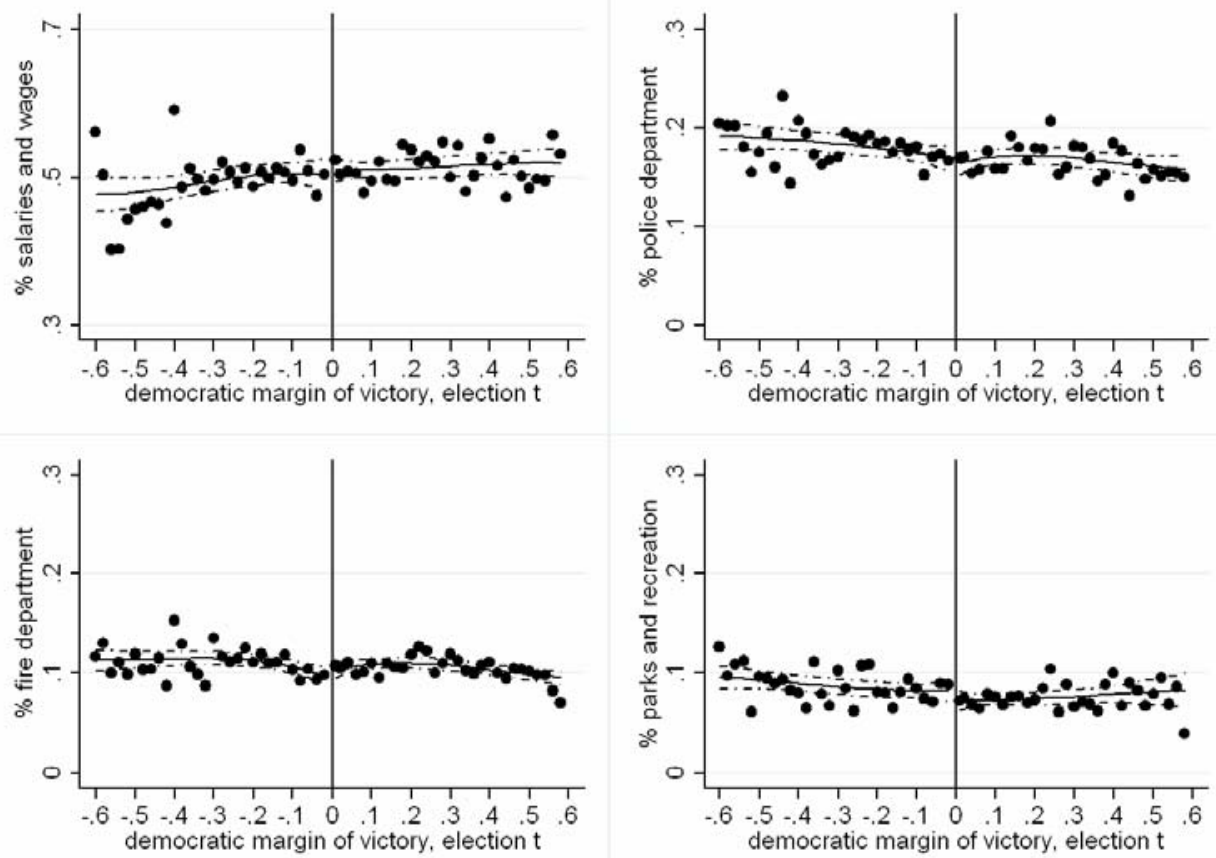

Notes: The panels (from top left to bottom right) refer to the following allocations as a percentage of total current expenditures: salaries and wages, police department, fire department and parks and recreation. Each dot corresponds to the unconditional mean within intervals of 0.02 Democratic margin of victory in election $t$. The solid line represents the predicted values of a third-order polynomial fit described in equation ( $\left.3^{\prime}\right)$, with the dashed lines showing the 95\% confidence intervals.

Figure 6. Party effect on crime
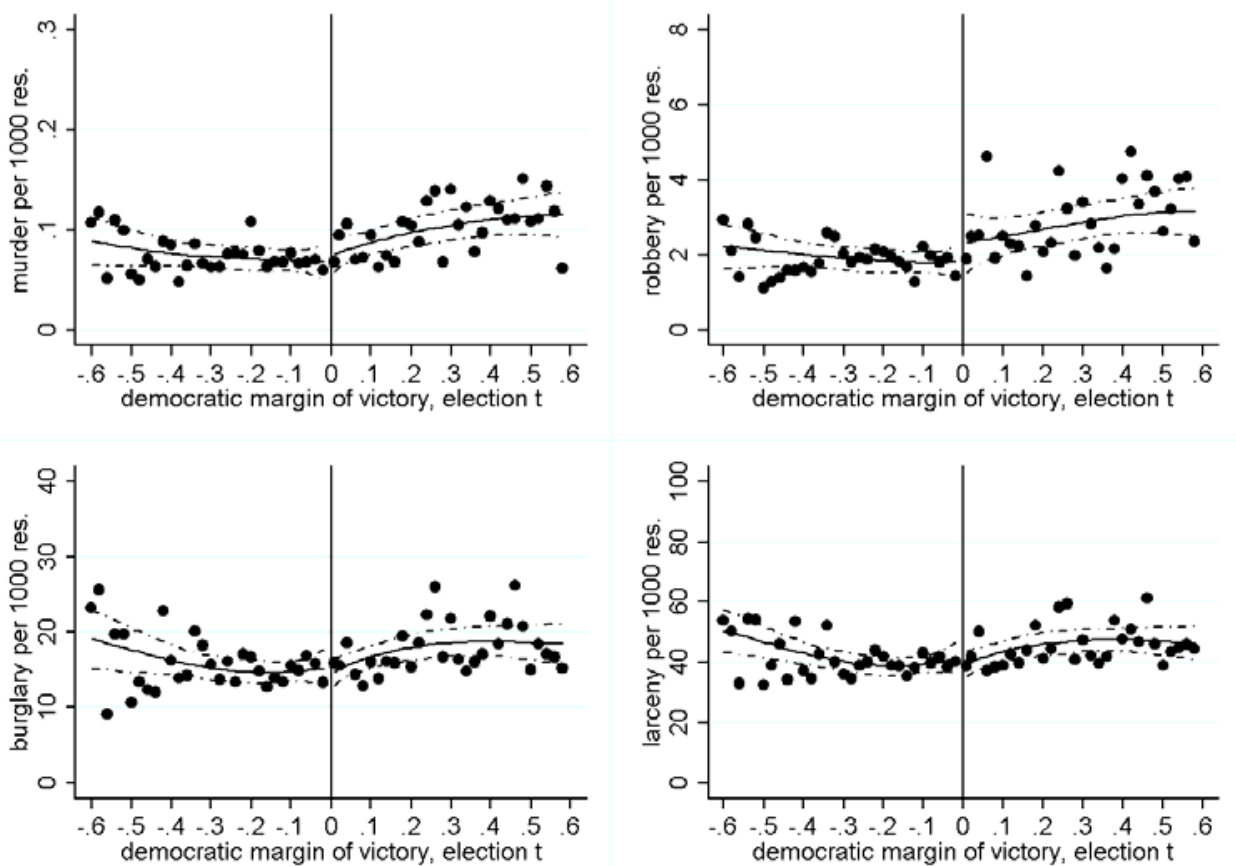

Notes: The panels (from top left to bottom right) refer to the following actual crime outcomes per 1,000 residents: murders, robberies, burglaries and larcenies. Each dot corresponds to the unconditional mean within intervals of 0.02 Democratic margin of victory in election $t$. The solid line represents the predicted values of a third-order polynomial fit described in equation (3'), with the dashed lines showing the $95 \%$ confidence intervals. 
Figure 7. Validity test: demographics
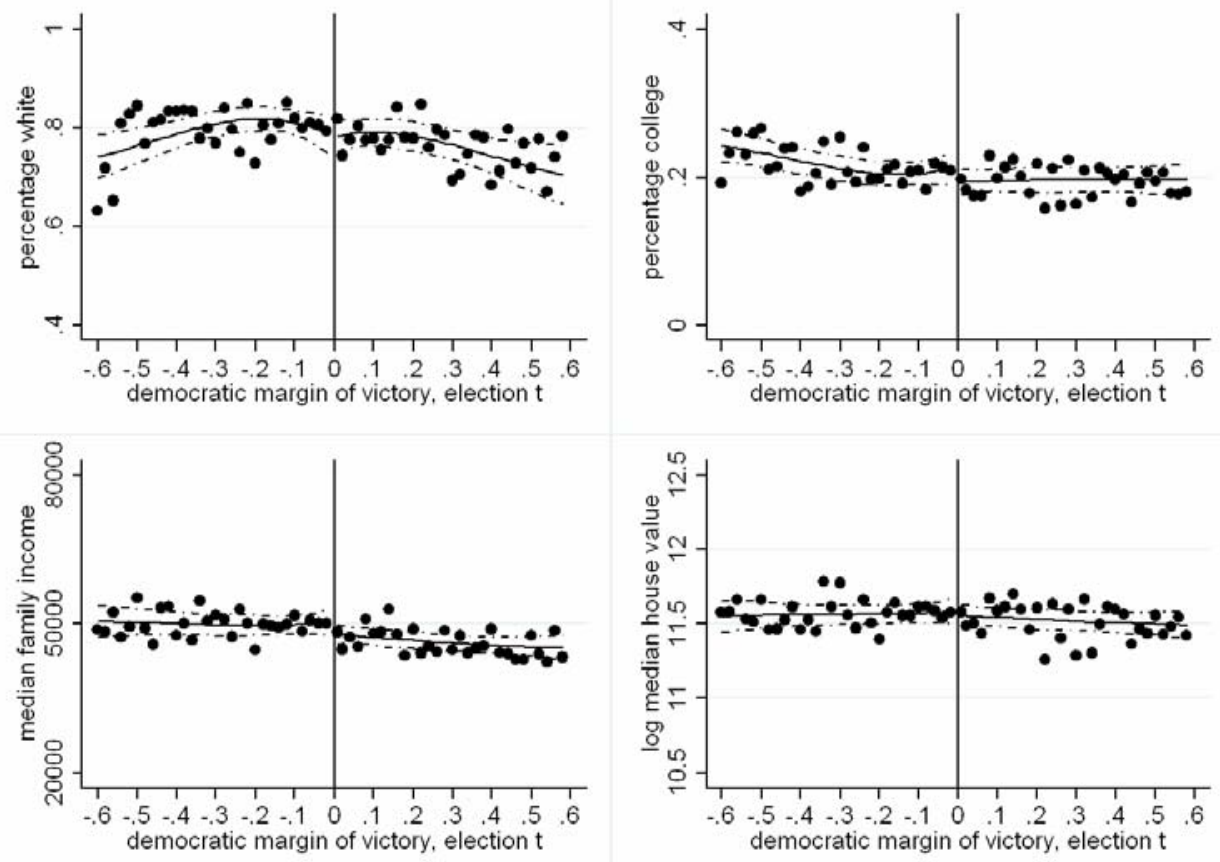

Notes: The panels (from top left to bottom right) refer to the following city characteristics: percentage white, percentage college degree or more, median family income and log median house value of owner occupied houses. All monetary measures are as of year 2000. Each dot corresponds to the unconditional mean within intervals of 0.02 Democratic margin of victory in election $t$. The solid line represents the predicted values of a third-order polynomial fit described in equation (3'), with the dashed lines showing the $95 \%$ confidence intervals. 
Appendix Table 1. Robustness tests

\begin{tabular}{|c|c|c|c|c|}
\hline \multirow[b]{2}{*}{ dependent variables } & \multicolumn{4}{|c|}{ RD Cubic, $\%$ difference between Dems and Reps } \\
\hline & $\begin{array}{c}\text { small cities } \\
(<=60000) \\
(1)\end{array}$ & $\begin{array}{c}\text { big cities } \\
(>60000) \\
(2)\end{array}$ & $\begin{array}{c}\text { last year } \\
\text { of the term } \\
\text { (3) }\end{array}$ & $\begin{array}{c}\text { 4-year term } \\
\text { cities } \\
(4) \\
\end{array}$ \\
\hline \multicolumn{5}{|l|}{ size of government } \\
\hline total revenues & $\begin{array}{c}0.020 \\
(0.078)\end{array}$ & $\begin{array}{c}0.036 \\
(0.074)\end{array}$ & $\begin{array}{c}0.016 \\
(0.060)\end{array}$ & $\begin{array}{l}-0.031 \\
(0.076)\end{array}$ \\
\hline total taxes & $\begin{array}{l}-0.055 \\
(0.080)\end{array}$ & $\begin{array}{c}-0.017 \\
(0.069)\end{array}$ & $\begin{array}{l}-0.010 \\
(0.055)\end{array}$ & $\begin{array}{l}-0.008 \\
(0.074)\end{array}$ \\
\hline total expenditures & $\begin{array}{c}0.019 \\
(0.080)\end{array}$ & $\begin{array}{c}0.033 \\
(0.075)\end{array}$ & $\begin{array}{c}0.027 \\
(0.061)\end{array}$ & $\begin{array}{l}-0.018 \\
(0.077)\end{array}$ \\
\hline total employment per 1000 residents & $\begin{array}{l}-0.025 \\
(0.083)\end{array}$ & $\begin{array}{c}0.032 \\
(0.076)\end{array}$ & $\begin{array}{c}0.063 \\
(0.061)\end{array}$ & $\begin{array}{c}0.045 \\
(0.083)\end{array}$ \\
\hline \multicolumn{5}{|l|}{ allocation of resources } \\
\hline$\%$ spent with salaries and wages & $\begin{array}{l}-0.002 \\
(0.018)\end{array}$ & $\begin{array}{c}0.003 \\
(0.018)\end{array}$ & $\begin{array}{c}0.011 \\
(0.014)\end{array}$ & $\begin{array}{l}-0.007 \\
(0.017)\end{array}$ \\
\hline$\%$ spent with police department & $\begin{array}{l}-0.011 \\
(0.012)\end{array}$ & $\begin{array}{c}0.008 \\
(0.011)\end{array}$ & $\begin{array}{c}0.004 \\
(0.009)\end{array}$ & $\begin{array}{l}-0.006 \\
(0.012)\end{array}$ \\
\hline$\%$ spent with fire department & $\begin{array}{c}0.005 \\
(0.009)\end{array}$ & $\begin{array}{c}0.006 \\
(0.007)\end{array}$ & $\begin{array}{c}0.009 \\
(0.006)\end{array}$ & $\begin{array}{c}0.004 \\
(0.008)\end{array}$ \\
\hline$\%$ spent with parks and recreation & $\begin{array}{c}0.004 \\
(0.012)\end{array}$ & $\begin{array}{c}-0.007 \\
(0.008)\end{array}$ & $\begin{array}{l}-0.003 \\
(0.007)\end{array}$ & $\begin{array}{l}-0.011 \\
(0.008)\end{array}$ \\
\hline \multicolumn{5}{|l|}{ crime indexes } \\
\hline murder per 1000 residents & $\begin{array}{c}0.004 \\
(0.008)\end{array}$ & $\begin{array}{l}-0.005 \\
(0.013)\end{array}$ & $\begin{array}{l}-0.003 \\
(0.009)\end{array}$ & $\begin{array}{c}0.003 \\
(0.013)\end{array}$ \\
\hline robbery per 1000 residents & $\begin{array}{c}0.999 \\
(0.778)\end{array}$ & $\begin{array}{c}-0.112 \\
(0.354)\end{array}$ & $\begin{array}{l}-0.061 \\
(0.220)\end{array}$ & $\begin{array}{c}0.671 \\
(0.830)\end{array}$ \\
\hline burglary per 1000 residents & $\begin{array}{l}-0.003 \\
(1.501)\end{array}$ & $\begin{array}{l}-1.121 \\
(1.799)\end{array}$ & $\begin{array}{l}-1.323 \\
(1.323)\end{array}$ & $\begin{array}{l}-1.813 \\
(2.053)\end{array}$ \\
\hline larceny per 1000 residents & $\begin{array}{c}1.022 \\
(4.349)\end{array}$ & $\begin{array}{l}-2.125 \\
(3.649)\end{array}$ & $\begin{array}{l}-2.609 \\
(3.082)\end{array}$ & $\begin{array}{l}-4.559 \\
(4.841)\end{array}$ \\
\hline covariates & YES & YES & YES & YES \\
\hline observations & 1029 & 964 & 1906 & 914 \\
\hline
\end{tabular}

Notes: The table presents RD coefficient estimates of each fiscal policy outcome on an indicator for Democrat victory in election $\mathrm{t}$ as described in equation ( $\left.3^{\prime}\right)$ in the text. Column 1 restricts the sample to cities with less than 60,000 people, while Column 2 restricts the sample for cities with more than 60,000. Column 3 uses independent variables defined as of the last year of the term (instead of the average of the term), and Column 4 restricts the sample to 4-year term elections. All size of government variables were transformed to logs. Covariates include city population, the type of election (partisan versus non-partisan, length of term status), median income, percentage of white households, percentage of households with college degree, homeownership rate and the median house value. Year and region fixed effects also are included. Reported standard errors are based on clustering by city and decade. 